\title{
8. RADIOLARIANS FROM THE WESTERN MARGIN OF THE ROCKALL PLATEAU: DEEP SEA DRILLING PROJECT LEG 81
}

\author{
M. J. Westberg-Smith and W. R. Riedel, Geological Research Division, Scripps Institution of Oceanography ${ }^{2}$
}

\begin{abstract}
Radiolarians occur at all Leg 81 sites in Neogene to Quaternary sediments and at Sites 552 and 553 in Eocene cores. Upper Pliocene through Pleistocene glacial sediments are barren of siliceous fossils, and the lowest part of the upper Miocene is barren of radiolarians at all but Site 555. Their presence at Site 555 is probably due to more rapid burial resulting from lateral influx of current-borne sediment. Radiolarians at each site are recorded in percent abundance for 95 Neogene counting groups and 31 Eocene groups.
\end{abstract}

\section{INTRODUCTION}

A total of eight holes at four sites were drilled during Leg 81 on the western margin of the Rockall Plateau:

\begin{tabular}{ccc}
\hline Site & Location & $\begin{array}{c}\text { Water depth } \\
(\mathrm{m})\end{array}$ \\
\hline 552 & $56^{\circ} 02.56^{\prime} \mathrm{N}, 23^{\circ} 13.88^{\prime} \mathrm{W}$ & 2301 \\
553 & $56^{\circ} 05.32^{\prime} \mathrm{N}, 23^{\circ} 20.61^{\prime} \mathrm{W}$ & 2329 \\
554 & $56^{\circ} 17.41^{\prime} \mathrm{N}, 23^{\circ} 31.69^{\prime} \mathrm{W}$ & 2574 \\
555 & $56^{\circ} 33.70^{\prime} \mathrm{N}, 20^{\circ} 46.93^{\prime} \mathrm{W}$ & 1659 \\
\hline
\end{tabular}

Radiolarians are present in lower Eocene through lower Pliocene sediments of these cores. Preservation varies from poor to moderate, and some of the middle to upper Miocene and upper Pliocene through Pleistocene sequences are barren of siliceous fossils. Figure 1 summarizes occurrences of calcareous and siliceous fossils in Leg 81 cores.

\section{PROCEDURES}

Generally, we took two to three samples per core, sieved at $44 \mu \mathrm{m}$, acidified, and prepared strewn slides in our standard manner. Relative abundances of 95 counting groups are recorded in Tables 1-3 as percentages of 350-400 radiolarians counted in diagonal traverses across the slide. These tables also include an estimate of the proportion of the microscopic field covered by diluting components such as mineral grains, diatoms, or sponge fragments.

\section{ZONATION}

The Pliocene Sphaeropyle langii Zone of Foreman (1975) and the Pliocene through middle Miocene zones of Riedel and Sanfilippo (1970, emend. 1978) are used in this chapter. In several cores zonal boundaries based on evolutionary transitions are uncertain because the evolving forms are very rare. The boundary between the Didymocyrtis antepenultima Zone and the $D$. penulti$\mathrm{ma}$ Zone is not discernible in any of the Leg 81 material, so these two zones are combined and used for samples above the range of $D$. laticonus and below the evo-

\footnotetext{
${ }^{1}$ Roberts, D. G., Schnitker, D., et al., Init. Repts. DSDP, 81: Washington (U.S. Govt. Printing Office).

2 Address: Geological Research Division, Scripps Institution of Oceanography, University of California, San Diego, La Jolla, CA 92093.
}

lutionary bottom of Stichocorys peregrina. Since Diartus petterssoni and $D$. hughesi are very rare or absent, samples above the evolutionary transition from Lithopera renzae to $L$. neotera are considered in the $D$. petterssoni Zone, and those below are assigned to the Dorcadospyris alata Zone. None of the lower Miocene to Oligocene sediments contained the radiolarian species necessary for zonation, and although radiolarian assemblages in samples dated on the basis of other fossil groups as lower Eocene were distinct from those of the middle Eocene, markers of established Eocene zones were not found. Figure 2 presents radiolarian zones for Leg 81 cores.

\section{SITE 552}

Site 552 is located on the Hatton Drift on the western margin of the Rockall Plateau. Twenty-five rotary-drilled cores were taken at Hole 552, which was spot cored to $108 \mathrm{~m}$ and then continuously cored to basalt. Hole 552A was piston cored to $183.5 \mathrm{~m}$ and terminated in middle Eocene sediments.

In the upper Pliocene and Pleistocene sediments of Cores 552-1 and 552A-1 through 12, radiolarians are poorly preserved, rare, and diluted with nonbiogenic components, and some samples are entirely barren of siliceous microfossils. Between Cores 552A-10 and 20 there is a minor component of robust radiolarians reworked from the lower Miocene (Table 1). Many samples from this interval contain some radiolarians that are rather poorly preserved, and others very well preserved, sometimes even including phaeodarians. The latest occurrence of Stichocorys peregrina (between Sample 552A-13,CC and Section 552A-14-1) occurs lower than expected in relation to other microfossil groups. It may be that its range is shorter in the Atlantic than in the Pacific, or perhaps the extinction appears to be early because the species becomes very rare at the top of its range. Cores between this event and the evolutionary transition between Sphaeropyle robusta and S. langii (between Samples 552A-25,CC and 552A-26-1, 65-66 cm) are placed in the $S$. langii Zone. In this interval radiolarians are, with a few exceptions, well preserved and fairly abundant on the strewn slides. Several samples (in particular, Samples 552A-19,CC and 552A-21-3, 66-68 cm) have 


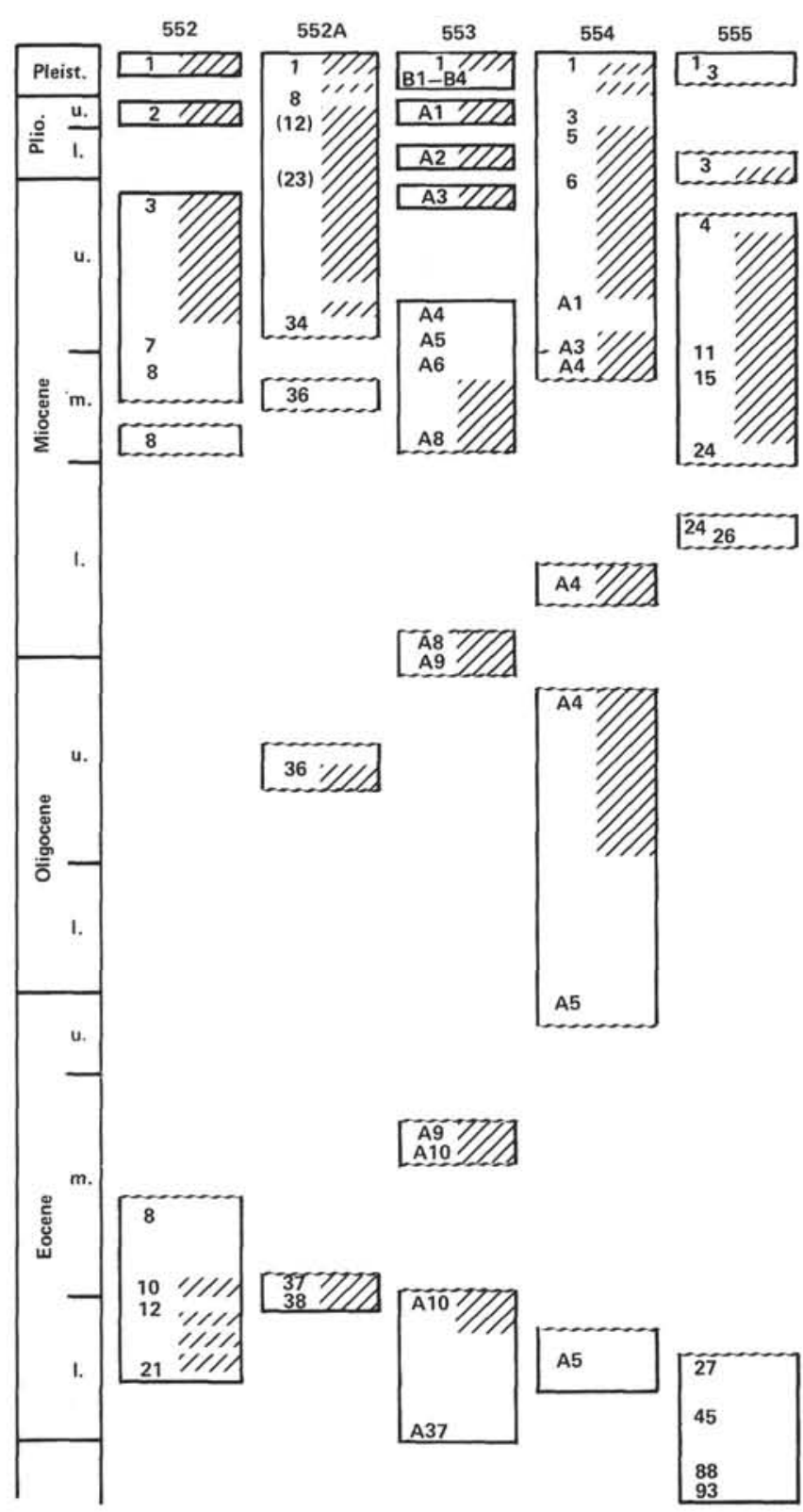

Figure 1. Sediments cored on Leg 81 on the western margin of Rockall Plateau. Cores are represented by numbered rectangles. Empty areas indicate sediments containing only calcareous microfossils, hachured areas indicate the presence of both calcareous and siliceous microfossils. Wavy lines represent hiatuses.

exceptionally well-preserved, abundant, and diverse radiolarians. Sections 552A-26-1 through 552A-29-1 and Cores 552-4 and 552-5 belong to the S. peregrina Zone. The event marking the lower boundary of this zone is the evolutionary transition of $S$. delmontensis to $S$. peregrina, which occurs between Section 552A-29-1 and Sample 552A-30,CC and between Sample 552-5,CC and Section 552-6-1. Just below this transition, there is an interval of approximately $30 \mathrm{~m}$ (Cores 552-7 through 552-9, and Sections 552A-31-3 through 552A-37-1) in which siliceous fossils are all or nearly all dissolved. There are two unconformities in this interval, one at Sample 552A-36-3, $139 \mathrm{~cm}$ with middle Miocene sediments overlying Oligocene, and a second at Sample
552A-37-1, $75 \mathrm{~cm}$ representing most of the late and middle Eocene (Backman, this volume). Benthic foraminifers in the lower part of this interval reveal subsidence from depths of $\sim 700 \mathrm{~m}$ in the middle Eocene to approximately the present-day depth of $2000 \mathrm{~m}$ above the hiatus (Murray, this volume). In the shallow-water lower and middle Eocene sediments, radiolarians are rare to common and diluted with large sponge spicules. Lophocyrtis norvegiensis, Ptercocodon ampla, and Phormocyrtis striata striata are common components of the middle Eocene assemblage in Sample 552-10,CC and Sections 552A-37 through 552A-38. Cores 552-12 through 552-21 contain fewer radiolarians, but in Section 552-18-2 there are some rather corroded tests that appear to be lower Eocene forms Amphicraspedum murrayanum and Pterocodon lex, and Sample 552-21-3, 47$49 \mathrm{~cm}$ contains the lower Eocene species Buryella tetradica (Table 3).

\section{SITE 553}

Site 553 is located some 4 miles northwest of Site 552. Hole 553 is a single mudline core, and Hole 553B consists of four disturbed piston cores. Hole 553A was drilled and spot cored to $179.5 \mathrm{~m}$ and then continuously cored through Eocene sediment and into basalt.

Radiolarians are common and moderately well preserved in the Pliocene and upper Miocene Cores 553A-1 through 553A-3. It is not possible to distinguish between the Stichocorys peregrina Zone and the Sphaeropyle langii Zone in these samples because $S$. langii and its ancestor $S$. robusta are equally rare in all the examined slides. Siliceous fossils are dissolved in Cores 553A-4 and $553 \mathrm{~A}-5$, an interval corresponding to the barren middle Miocene at Site 552. There are few poorly preserved radiolarians in the middle Miocene Core 553A-6 through Section 553A-8-3. Because artiscins are rare and poorly preserved in this sequence, the boundary between the Diartus petterssoni Zone and the Dorcadospyris alata Zone cannot be discerned, but the presence of Diartus laticonus, Lithopera neotera, and L. renzae in Samples 553A-7-4, 119-121 cm and 553A-8-1, 62-64 cm suggests that these cores are middle Miocene. Sections 553A-8-2 and 553A-8-3 can be assigned to the Dorcadospyris alata Zone because $L$. renzae is more abundant than is its descendant $L$. neotera, and this evolutionary transition occurs in the upper part of the D. alata Zone. Neogene radiolarians of Site 553 are tabulated in Table 2.

At least four radiolarian zones of the early Miocene are missing between the bottom of Section 553A-8-3 and the top of Section 553A-8-4. In Sample 553A-8-4, 19-21 $\mathrm{cm}$, radiolarians appear to be older than the early Miocene Cyrtocapsella tetrapera Zone because of the absence of Stichocorys delmontensis and C. tetrapera, both of which are common in the samples above. Artophormis gracilis, which ranges through the Oligocene into the lower Miocene, is present in all samples examined between Sections 553A-8-4 and 553A-9-5. Below an unconformity in Section 553A-9-6, Samples 553A-9,CC through 553A-10-2, 122-124 cm contain a moderately well-preserved middle Eocene assemblage. Samples from Sections 553A-10-3 and 553A-10-4 are barren of siliceous 


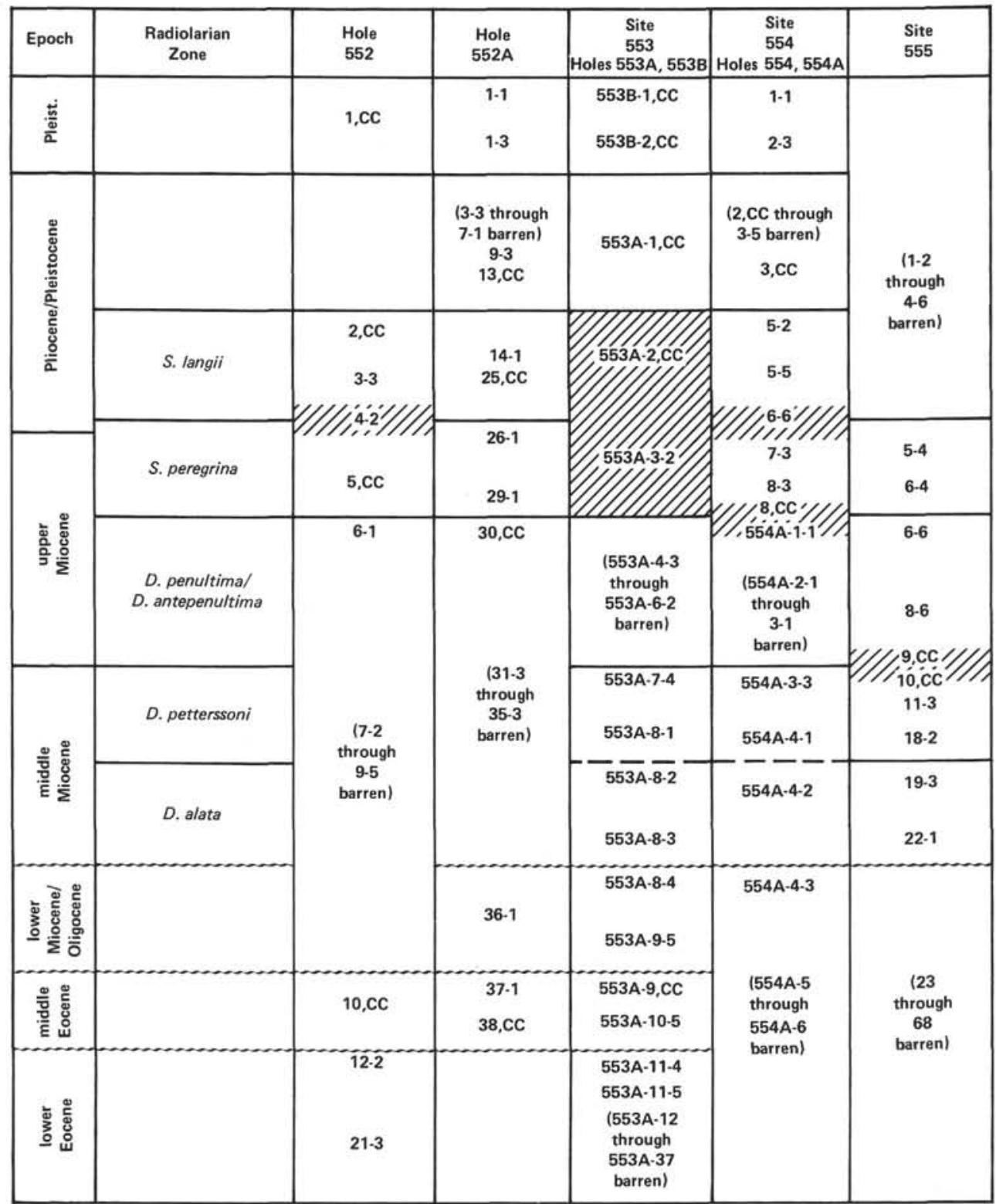

Figure 2. Radiolarian zones represented in Leg 81 sites. Cores and sections of each hole are shown. Hachured areas indicate uncertain zonal assignment. Wavy lines indicate hiatuses.

fossils, but Sample 553A-10-5, 98-100 cm contains a few moderately well-preserved middle to upper Eocene forms, and Core 553A-11 contains a lower Eocene fauna. These Eocene samples are tabulated, together with those from Site 552, in Table 3.

\section{SITE 554}

Site 554 is located on the outer high of the southwest margin of Rockall Plateau. Fourteen rotary cores were taken from two holes, terminating in lower Eocene sediments above basalt. Moderately well-preserved radiolarians are present in sediments down through the Oligocene with the exception of barren intervals in the Pleistocene, upper Miocene, and lower Eocene which correspond to the barren intervals in Sites 552 and 553.

Some samples from Pleistocene Cores 554-1 through 554-3 contain moderately well-preserved radiolarians.
Samples 554A-1-1, 44-46 cm through 554A-2-3, 12-14 $\mathrm{cm}$ are above the extinction of Stylatractus universus. Core 554-5 is assigned to the Sphaeropyle langii Zone on the co-occurrence of $S$. langii and $S$. peregrina, and samples from cores down to Section 554-8-3 are placed in the $S$. peregrina Zone. Samples $554-8, C C$ and $554 \mathrm{~A}-$ $1-1,18-20 \mathrm{~cm}$ are apparently very near the evolutionary transition from Stichocorys delmontensis to $S$. peregri$n a$ and therefore near the boundary between the $S$. peregrina and Didymocyrtis penultima zones. A barren interval follows between the bottom of Core 554A-1 and the top of Core 554A-3. Below Section 554A-3-3 radiolarians are poorly preserved, but the presence of $D$. laticonus and Cyrtocapsella japonica suggest an age equivalent to the Diartus petterssoni or Dorcadospyris alata zones of the middle Miocene. These species and the common occurrence of $C$. tetrapera with rare Lithopera 
Table 1. Abundances of Neogene radiolarian counting groups at Site 552.

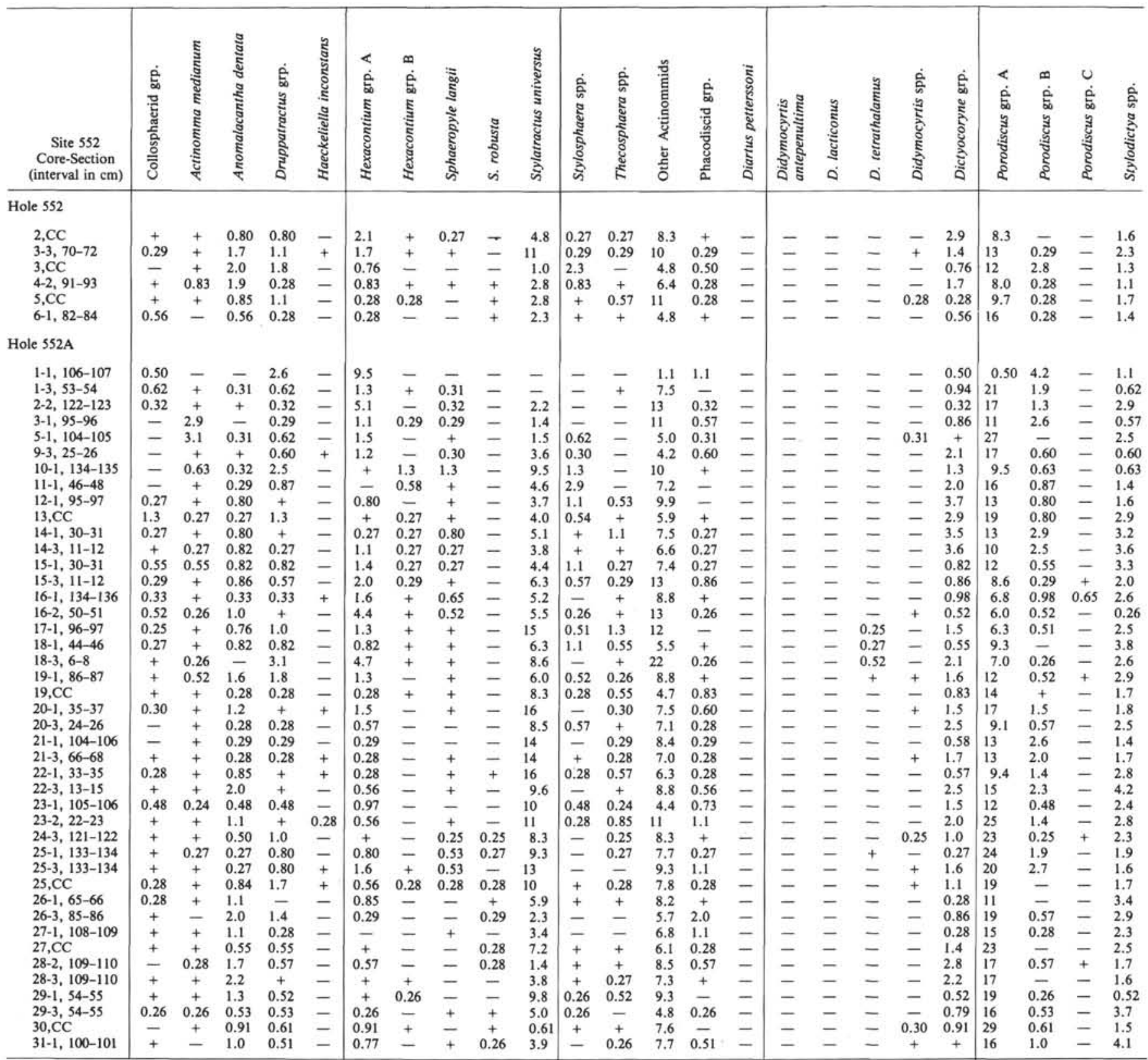

Note: In the body of the table, "-" indicates that the group was sought but not found, " + " indicates $<0.25 \%$ of the radiolarians on the slide, and numbers indicate abundance in percentage of total radiolarians on the slide as determined by counting the number of individuals indicated in the column headed "Radiolarians counted." The last columns on the right show the number of radiolarians on the slide, their preservation $(\mathrm{G}=\operatorname{good} ; \mathrm{M}=$ moderate; and $\mathrm{P}=$ poor), and the concentration of diluting components expressed as a percentage of the particles in a field of view.

renzae place Sample 554A-4-2, 2-4 cm in the $D$. alata Zone. The absence of $C$. tetrapera in an assemblage similar to that in Sections 553A-8-4 through 553A-9-3 places Sample 554A-4-3, 18-20 cm below the lower Miocene $C$. tetrapera Zone. Samples below $554 \mathrm{~A}-4, \mathrm{CC}$ are barren of radiolarians. Radiolarian occurrences in Site 554 are shown in Table 2.

\section{SITE 555}

Site 555 , located in a basin between the Hatton and Edoras banks, is the shallowest site of Leg 81. Radiolarians are present in Pliocene to middle Miocene Samples $555-4, \mathrm{CC}$ through 555-23,CC. The lower Miocene and shelfal lower Eocene sediments of Cores 555-24 through 555-67 are barren of siliceous fossils.

Sample $555-4, C C$ contains only large, indeterminate actinommids, litheliids, and spongodiscids, but in Core 555-5 there is a moderately well-preserved assemblage of the Stichocorys peregrina Zone. The dominance of $S$. delmontensis over $S$. peregrina in Sample 555-6-6, 30-32 $\mathrm{cm}$ indicates an age below the lower boundary of the $S$. peregrina Zone, but the species necessary to distinguish between the Didymocyrtis penultima Zone and $D$. antepenultima Zone are not present. Core catchers from Cores 555-9 and 555-10 contain very few robust radiolarians and large sponge spicules; most diagnostic species have evidently dissolved, but several specimens of 
Table 1. (Continued).

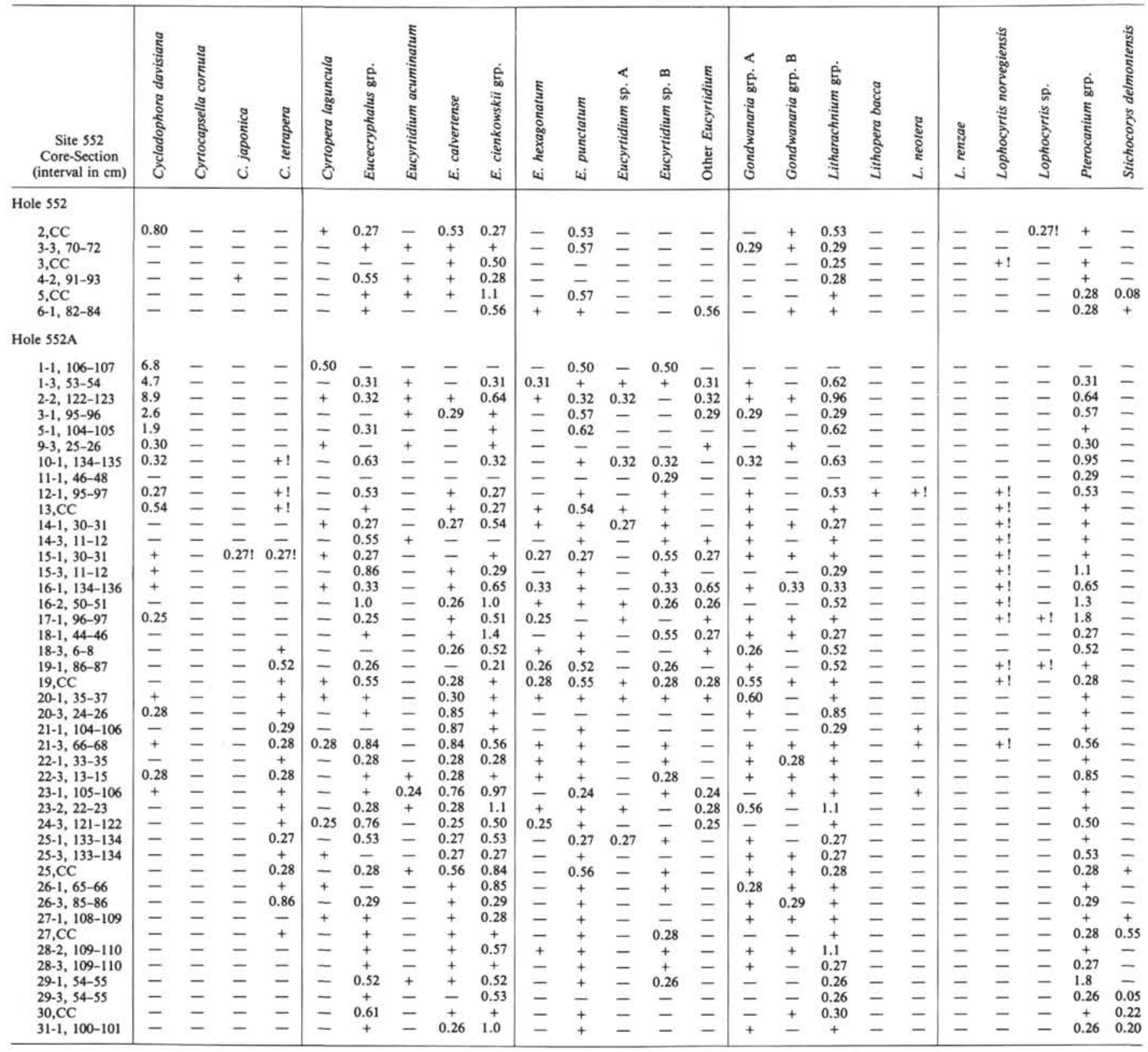

D. laticonus indicate middle to late Miocene age. There is more variety, better preservation, and greater abundance of radiolarians in samples below Sample 55510, CC. Although most of the artiscins are not sufficiently well preserved for species distinction, more $D$. laticonus are preserved than $D$. antepenultima, suggesting that Cores 555-11 through 555-18 belong in the Diartus petterssoni Zone. D. petterssoni is also present in this interval, along with Lithopera neotera and other species that range through this zone. The same assemblage persists down through Sample 555-16,CC, but that in Sample $555-17, \mathrm{CC}$ is noticeably different. There are abundant large sponge spicules; radiolarians that are abundant in the cores above are very rare or absent, and other forms are common. L. neotera is found in small numbers down to Core 555-21, where its ancestor $L$. renzae is more abundant. This evolutionary transition occurs in the upper part of the Dorcadospyris alata Zone.

Recovery in Cores 555-22 and 555-23 was very poor and most of the siliceous material is dissolved; only large robust actinommids and large sponge spicules remain in Core 22 . There is apparently a great deal of downhole contamination in Core 23. In addition to the partly dissolved radiolarians and sponge spicules like those in Core 555-22, there are small forms with very well-preserved delicate spines, and species characteristic of the Pliocene and Pleistocene. Below this, radiolarians are absent except for occasional occurrences of robust, nondiagnostic actinommids. Radiolarian abundances at Site 555 are tabulated in Table 2. 
Table 1. (Continued).

\begin{tabular}{|c|c|c|c|c|c|c|c|c|c|c|c|c|c|c|c|c|c|c|c|c|c|c|c|c|c|c|}
\hline 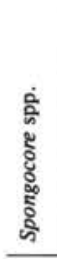 & 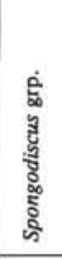 & 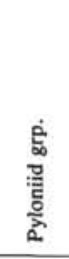 & 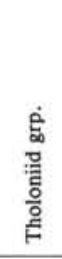 & 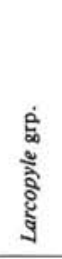 & 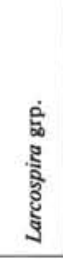 & $\begin{array}{l}\text { 气े } \\
\text { है } \\
\text { 气ू๊ } \\
\text { 气ू }\end{array}$ & 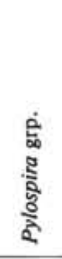 & 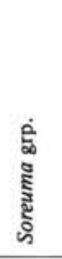 & 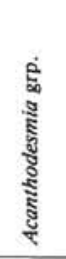 & 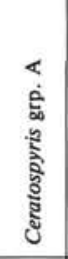 & 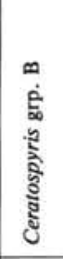 & 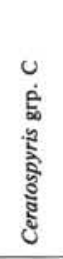 & 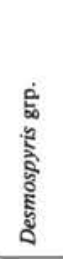 & 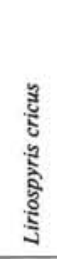 & 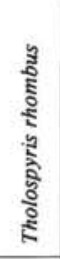 & 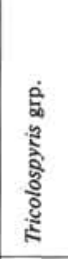 & 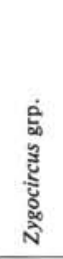 & 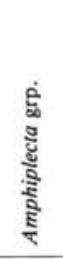 & 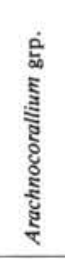 & 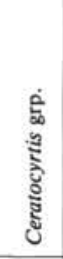 & 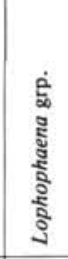 & 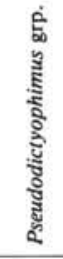 & 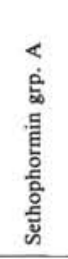 & 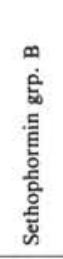 & 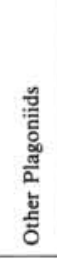 & 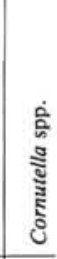 \\
\hline+ & 42 & 1.1 & - & - & - & 8.8 & 7.5 & - & + & + & + & + & - & - & - & - & + & + & + & 1.9 & 2.4 & 1.3 & + & - & - & - \\
\hline+ & 21 & 1.1 & - & 0.57 & 0.29 & 14 & 7.2 & - & - & 0.29 & - & - & - & - & - & - & - & + & - & 1.1 & 2.9 & 1.4 & 0.29 & - & - & + \\
\hline 0.50 & 34 & 2.3 & - & 1.8 & - & 15 & 6.3 & - & - & 0.25 & + & - & - & 1.5 & - & - & 0.25 & - & 0.25 & 1.0 & 1.0 & 0.50 & + & - & - & 0.76 \\
\hline $\begin{array}{c}0.55 \\
+\end{array}$ & 25 & 3.3 & 0 & 0 & - & 19 & 5.5 & - & + & + & - & - & 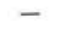 & .1 & - & 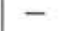 & + & - & 1.1 & 4.2 & 3.6 & 0.55 & 0.28 & - & 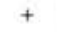 & 2.2 \\
\hline$\stackrel{+}{+.56}$ & 24 & 2.3 & 0.28 & 0.57 & - & 19 & 9.4 & - & $\overline{0}$ & + & - & - & - & - & - & - & - & - & 28 & 0.85 & 3.4 & + & - & - & - & 2.3 \\
\hline 0.56 & 12 & 2.0 & 0.28 & 0.85 & - & 19 & 9.6 & - & 0.28 & 0.56 & 0.56 & - & - & - & - & - & - & - & 0.85 & 2.5 & 3.7 & 0.56 & - & - & 0.28 & + \\
\hline 1.1 & 8.4 & - & - & 1.1 & - & 36 & 8.4 & 1.1 & - & - & - & - & - & - & - & - & - & - & - & - & 1.1 & 5.3 & - & 0.50 & - & 0.50 \\
\hline 0.94 & 15 & 0.31 & 0.62 & + & 0.62 & 25 & 6.9 & - & - & - & - & - & - & - & - & - & + & - & + & 0.94 & + & 1.9 & - & 0.31 & + & 0.31 \\
\hline 0.64 & 6.0 & 0.96 & + & 1.3 & - & 14 & 15 & - & 0.64 & - & - & - & - & - & - & - & - & - & 0.32 & 1.6 & 1.3 & 2.2 & - & 0.64 & + & 0.32 \\
\hline 1.1 & 12 & 0.57 & - & 0.29 & - & 24 & 14 & - & - & - & - & - & - & - & - & - & - & - & - & - & 1.4 & 1.7 & - & 0.29 & 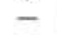 & 1.1 \\
\hline 0.31 & 8.4 & 0.62 & 0.62 & - & - & 25 & 7.1 & 0.62 & - & - & - & $=$ & - & - & - & - & - & - & 0.31 & - & 1.2 & 0.93 & - & - & 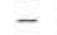 & 31 \\
\hline- & 19 & 0.60 & - & - & + & 2 & 1.8 & 0.30 & - & + & 0.60 & - & - & - & - & - & 0.30 & 0.30 & 0.30 & 0.60 & 14 & 2.1 & - & - & - & .2 \\
\hline- & 10 & 0.95 & - & 0.32 & 0.32 & 18 & 12 & - & + & + & - & - & - & - & - & - & - & - & + & 0.32 & \begin{tabular}{|l}
7.9 \\
\end{tabular} & 1.3 & - & + & 0.63 & 0.95 \\
\hline- & 28 & 0.58 & 1.7 & 0.58 & - & 2 & 8.4 & - & - & - & - & - & - & - & - & - & - & - & - & - & 3.2 & & - & - & - & 0.58 \\
\hline+ & 16 & 0.80 & - & - & - & 2 & 3.5 & - & 0.53 & 0.27 & + & - & + & - & - & + & + & + & 0.27 & 1.9 & 3.7 & 0.27 & + & - & 1.4 & 1.3 \\
\hline 0.27 & 24 & 0.27 & + & + & - & 1. & 2.2 & - & - & 0.27 & - & 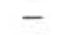 & 0.27 & 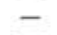 & 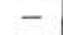 & - & + & 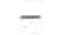 & 0.27 & & 8 & . & & - & 0.27 & 6 \\
\hline- & 2 & & + & - & + & 2 & & - & - & & + & 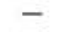 & - & - & - & $t$ & - & - & + & 0.54 & 1 & & & - & - & \\
\hline+ & 38 & 1.1 & 0.27 & 0.27 & - & 1 & 3. & - & + & 0.82 & 0.27 & - & - & - & - & - & - & - & 0.55 & 0.55 & 0.82 & 0.27 & - & - & - & 1.1 \\
\hline+ & 26 & 1.1 & 0.27 & 0.27 & - & 1 & 5.2 & - & - & 0.27 & 0.82 & - & - & - & - & - & + & - & .4 & 3.0 & 3.0 & 0.27 & - & - & 0.55 & 0.82 \\
\hline- & 17 & 2.0 & 0.57 & + & - & 1 & 9.1 & - & + & 0.29 & - & - & - & - & - & - & - & - & .86 & 1.7 & 6 & 0.29 & 0.29 & - & .57 & 1.7 \\
\hline+ & 24 & 1.3 & + & + & + & i & 1.7 & + & + & 0.33 & + & - & 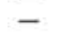 & - & - & - & + & 0.33 & & 2.6 & .6 & 2.0 & + & 0.33 & & 2.0 \\
\hline- & 2 & 1. & 0.26 & 1.8 & + & i & 6.0 & - & - & 0.26 & 0.52 & 0.26 & - & 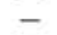 & 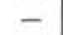 & - & 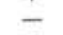 & 年 & 0.52 & & 4.4 & & 0.26 & + & 0.26 & 1.6 \\
\hline- & 20 & 0.76 & + & 1.8 & + & 1 & 11 & $-\overline{0}$ & - & 0.25 & - & - & - & - & - & - & - & - & + & 1. & 0.25 & 0.25 & 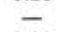 & - & + & 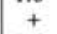 \\
\hline+ & 25 & 1.1 & - & 0.82 & + & 1 & 1.7 & 0.27 & 0.27 & + & - & + & - & - & - & - & - & 0.27 & 0.27 & 3.0 & 7.9 & 0.55 & 0.27 & 1.1 & 0.27 & 1.6 \\
\hline+ & 6.5 & 1.6 & - & - & - & . & 4. & - & - & 0.26 & + & - & - & - & - & - & - & - & 26 & 0.52 & .8 & - & - & - & - & 0.78 \\
\hline- & 16 & 0.52 & 0.26 & + & - & 1 & 9.1 & - & - & 0.52 & - & - & - & - & - & - & - & - & $1 .$. & 1.6 & & 0.52 & - & - & + & 1.6 \\
\hline+ & 2 & & - & 0.55 & 0.28 & 1 & 11 & - & - & + & + & - & 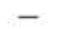 & - & + & + & + & - & t & & 3.0 & 0.28 & + & - & + & 0.28 \\
\hline 0.30 & 1 & 0.60 & - & 0.60 & - & 1 & 13 & - & + & + & - & - & - & - & 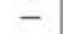 & - & + & + & & & & 0.30 & - & - & & ato \\
\hline 4 & 20 & 0 & 0.28 & + & - & 3 & 3.1 & - & - & - & - & - & - & - & 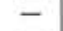 & 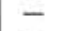 & - & - & 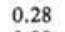 & 1 & 11 & - & - & + & T & 2.0 \\
\hline 0.29 & 24 & 0 & - & + & - & 2 & 4. & - & - & - & - & - & - & - & 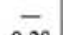 & . & - & - & 29 & 0.58 & 0.29 & - & - & - & 0 & 0.87 \\
\hline 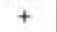 & 10 & 2 & 0.28 & 0.28 & - & 1 & 13 & - & + & + & - & - & + & - & 0.28 & 0.2 & + & + & & 2.8 & .8 & 1.1 & + & + & 0.28 & 1.1 \\
\hline+ & 6.9 & 0. & - & + & - & 2 & 1 & - & + & + & 0.28 & - & $t$ & - & + & - & + & - & 3. & 1 & 5.4 & 1.4 & + & + & 0.28 & 1.4 \\
\hline 0.28 & 12 & 3.4 & 0.28 & + & - & 1 & 10 & & + & + & 0.56 & 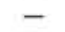 & & & - & - & 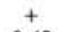 & & & 0.28 & 5. & 0.28 & + & + & + & 0.28 \\
\hline t & 9.2 & 0.48 & - & 0.24 & - & 17 & 7. & - & + & 0.48 & - & - & - & - & + & - & 0.48 & - & & & & 2.2 & + & + & + & 0. \\
\hline 0.85 & 13 & 1.8 & + & + & - & 9.3 & 7 & - & + & 0.28 & - & - & - & - & - & - & - & - & 85 & 0.85 & 7 & + & - & - & - & 0.56 \\
\hline t & 8.6 & 1. & - & 0.25 & + & 12 & 7 & & + & & 0.25 & - & & 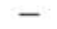 & & 0. & - & - & & & & 0.76 & - & - & 0.25 & 1.0 \\
\hline+ & 12 & 1. & - & & - & 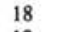 & 5.6 & - & - & 0.27 & - & - & - & - & & - & - & - & & & ri & 0.53 & + & - & + & 0.80 \\
\hline 0.27 & 8.2 & 2 & 0.27 & 0 & - & 1 & 12 & - & - & + & + & 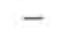 & & 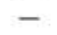 & & + & - & - & & 1 & 5.6 & - & - & - & + & 0.53 \\
\hline 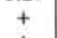 & 20 & 0 . & + & 0 & - & 1 & 3. & - & 0.28 & 0.2 & - & 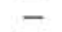 & & - & & & + & - & & & 4.2 & 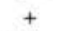 & 0.28 & - & 0.28 & 1.4 \\
\hline+ & 28 & 2 & 0. & 0.28 & - & 1 & 3 & - & 0.85 & & - & & & - & & - & . & - & 0.8 & & & 2. & + & + & 0.56 & 1.1 \\
\hline 0.29 & 14 & 2 & & + & - & 1 & 15 & - & - & 0 & - & - & - & - & & - & + & - & - & & 5.4 & 7 & - & - & - & $i 7$ \\
\hline & 1 & & 0. & \pm & + & 2 & 9 & - & + & 0.85 & 0.28 & - & 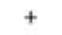 & & & & + & - & 0.57 & & & & + & - & + & 0.57 \\
\hline 0.83 & 11 & 1 & + & 2. & + & & & - & - & + & + & - & - & 0.83 & & 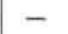 & + & + & + & 1.9 & 5.5 & & + & - & + & 1.9 \\
\hline 8 & 13 & 2. & T & 1 & - & i & 7 & - & 0.57 & 0.28 & 0.28 & - & 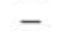 & + & - & 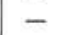 & - & - & 1. & i & 9.1 & 0.57 & 0.28 & - & + & 1.4 \\
\hline ( & 9.4 & 1. & & 1 & - & 1 & 9 & - & + & & + & - & - & - & - & & + & 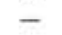 & 0. & i & 7 & 0.54 & - & - & + & \\
\hline 0.26 & 8. & & 0. & 0 & + & 1 & 9 & . & + & & + & & . & 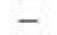 & - & 0.52 & 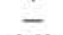 & - & 0.78 & & 5.4 & & & 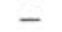 & + & \\
\hline+ & 1 & 1 & - & 1 & - & 1 & & - & + & & + & - & & - & - & - & 0.53 & 0.26 & 1.9 & 0.79 & 10 & & 0.26 & - & - & 1.6 \\
\hline 0 & 17 & 1.5 & - & 1.5 & - & 1 & 5.5 & - & - & 1.8 & - & - & - & - & - & - & - & - & + & 0.30 & 6.4 & 0.30 & - & - & + & 0.61 \\
\hline 0.51 & 12 & 0.77 & + & 0.26 & + & 18 & 8.5 & - & + & 0.77 & + & - & - & - & - & - & 0.26 & - & 1.3 & 1.3 & 8.0 & 1.8 & - & - & + & 1.8 \\
\hline
\end{tabular}

\section{DISCUSSION}

The oldest sediments in Leg 81 cores provide a record of rapid accumulation of mostly terrigenous and volcaniclastic components in shallow water during the early Eocene. Radiolarians are dissolved or poorly preserved during much of this interval but are well preserved in a few of the cores. Some of the species are similar to forms from the Norwegian Sea illustrated by Bjørklund (1976), most notably Lophocyrtis norvegiensis and a form herein called Pterocodon ampla which is generally larger than low-latitude specimens but not as large as Calocyclas talwanii Bjøklund and Kellogg (1972). The Eocene assemblages also have many components in common with those described from the Caribbean and Gulf of Mexico (Riedel and Sanfilippo, 1970; Sanfilippo and
Riedel, 1973), but the Podocyrtis and Thyrsocyrtis lineages are not represented.

A period of subsidence and erosion during the middle Eocene to early Miocene is marked by hiatuses at all Leg 81 sites. Radiolarians are preserved in the few cores that contain remnants of the Oligocene and lower Miocene record. Another hiatus is found at all sites between lower and middle Miocene sediments. This hiatus may indicate a change of circulation in the Atlantic basin, possibly related to the subsidence of the Iceland-Faeroes Ridge and the onset of sediment drift deposition in the Rockall area (Roberts, this volume). There is a striking difference between Site 555 and the other Leg 81 sites in both the thickness of upper to middle Miocene sediments and the preservation of siliceous fossils in these sediments. At Site 555, 11 cores represent two middle Mio- 
Table 1. (Continued).

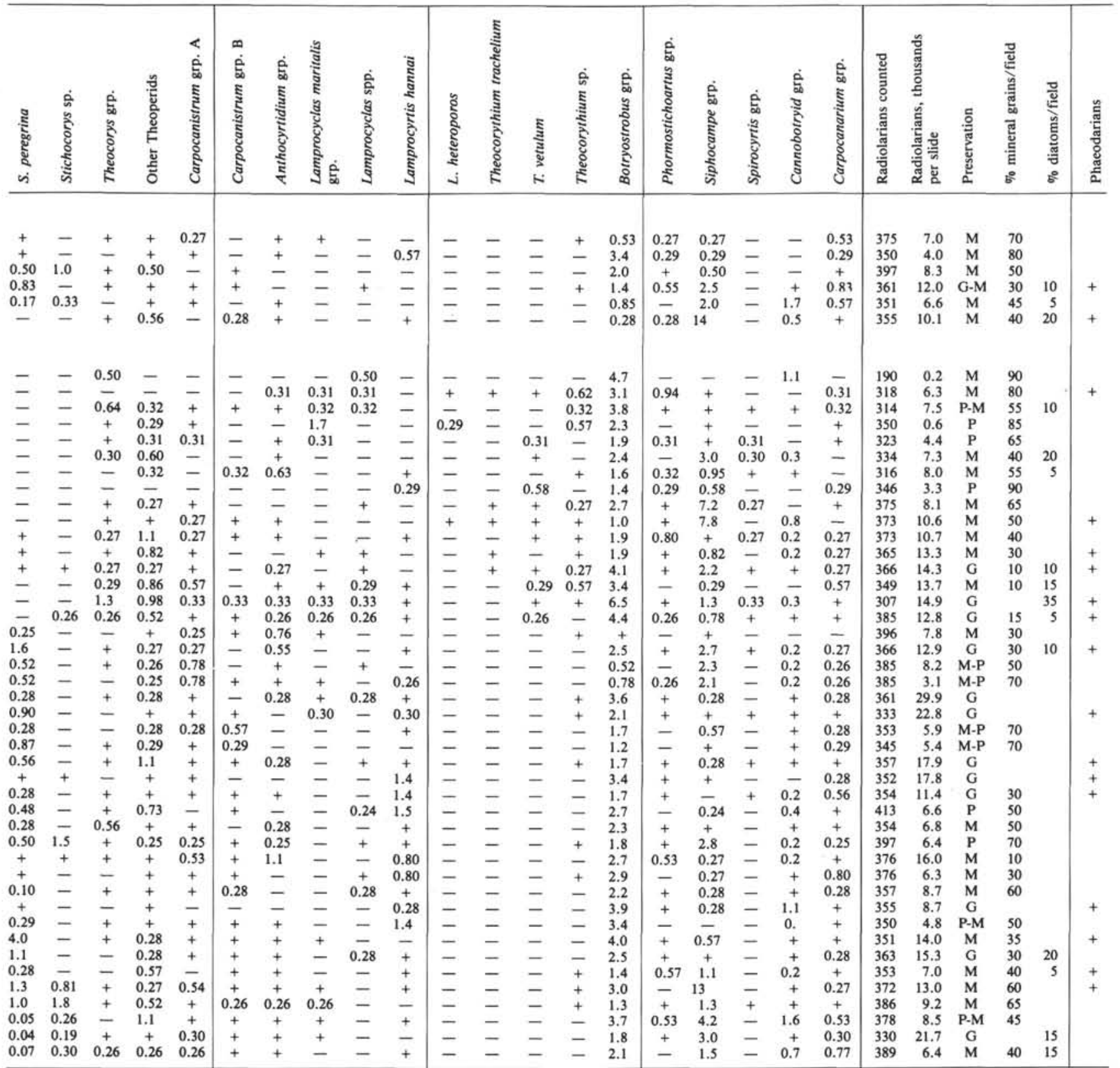

cene radiolarian zones; the same zones are contained in only one core from Sites 554 and 553 and not recorded at all at Site 552 (Fig. 2). Although the sedimentation rates of Sites 552, 553, and 554 are approximately constant in the upper Miocene, the fluctuation in relative amounts of calcareous nannofossils and planktonic foraminifers indicates that the availability of sediments deposited may have been controlled by the changing strength and position of currents in relation to the sites. The thickness of the upper Miocene section at Site 555 is most likely a result of these current-borne sediments, and the consequent rapid burial of siliceous skeletons enhanced the preservation of radiolarians.

Sediments deposited after the onset of glaciation in the late Pliocene contain very few robust radiolarians.
This may be due to dissolution, possibly associated with low productivity, and there is certainly also dilution by terrigenous minerals in the glacial marls and muds.

\section{TAXONOMIC NOTES}

\section{Family Collosphaeridae Müller, 1858}

\section{Collosphaerid group}

All collosphaerids are counted together in this chapter.

Family Actinommidae Haeckel, 1862, emend. Riedel, 1967b

Genus Actinomma Haeckel, 1860b

Actinomma medianum Nigrini (Plate 1, Figs. 1A, B)

Actinomma medianum Nigrini, 1967, p. 27, pl. 2, figs. 2a, b. 
Table 2. Abundances of Neogene radiolarian counting groups at Sites 553, 554, and 555. For explanation of symbols see note on Table 1.

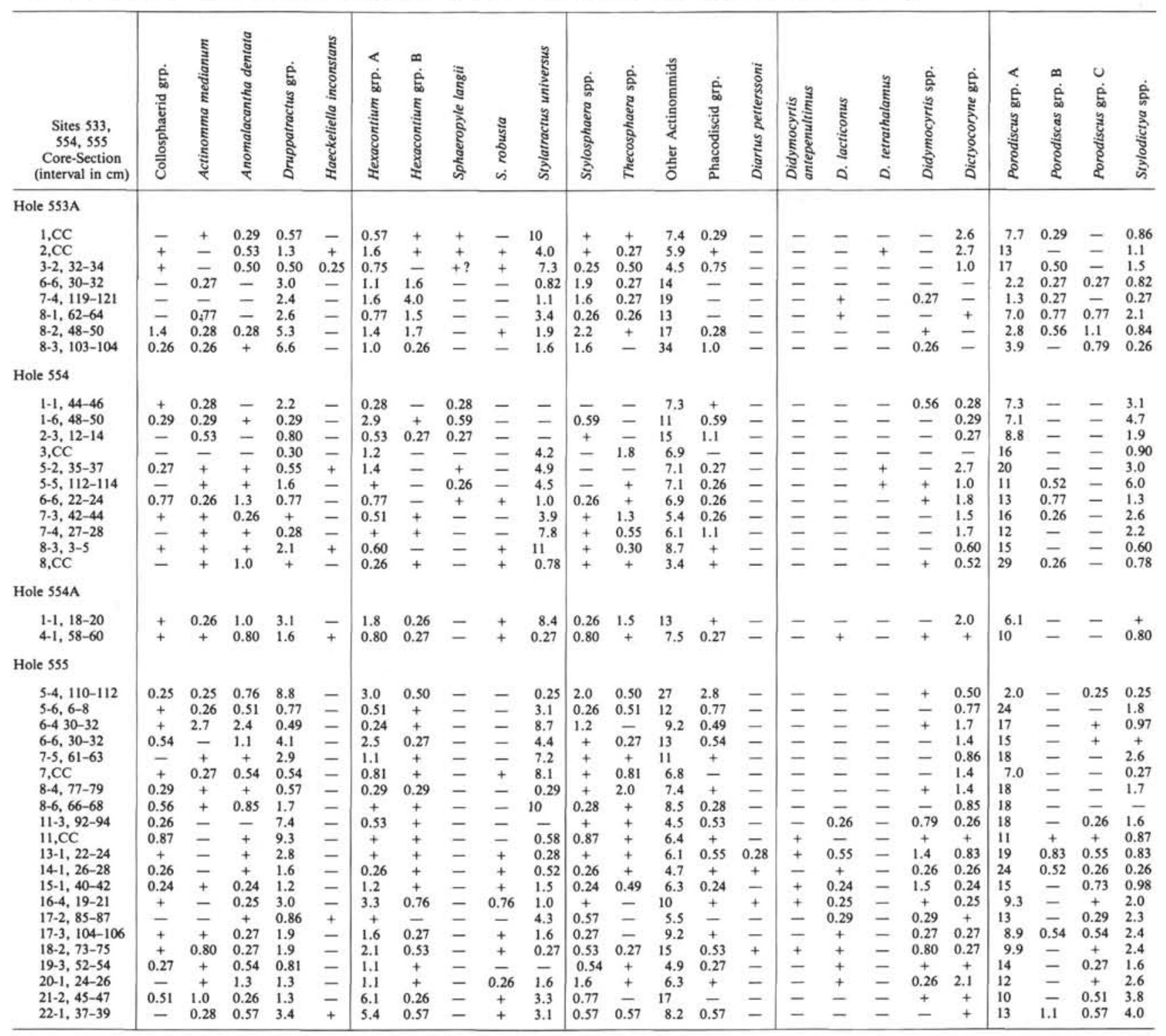

Genus Amphisphaera Haeckel, 1881

\section{Amphisphaera minor (Clark and Campbell)}

Stylosphaera minor Clark and Campbell, 1942, p. 27, pl. 5, figs. $1,2,2 \mathrm{a}, 12$.

Amphisphaera minor (Clark and Campbell)-Sanfilippo and Riedel, 1973 , p. 486 , pl. 1, figs. $1-5$, pl. 22 , fig. 4

Genus Anomalacantha Loeblich and Tappan, 1961

Anomalacantha dentata (Mast) (Plate 1, Fig. 3)

Heteracantha dentata Mast, 1910, p. 157

Anomalacantha dentata (Mast), Benson, 1966, p. 170, pl. 5, figs. 10,11 .

\section{Genus Druppatractus Haeckel, 1887}

\section{Druppatractus group (Plate 1, Fig. 2)}

Bipolar actinommid with pear-shaped medullary shell and coarse pores (less than eight across a half equator). Polar spines may be coni$\mathrm{cal}$ or bladed, equal or unequal in length.
Genus Haeckeliella Hollande and Enjumet, 1960

Haeckeliella inconstans Dumitricà

Haeckeliella inconstans Dumitrică, 1973, p. 833, pl. 7, figs. 1, 2, pl. 18 , figs. $7-22$.

\section{Genus Hexacontium Haeckel, 1881}

Hexacontium group A (Plate 1, Figs. 4A, B)

Spherical form with two medullary shells and six to seven spines in three mutually perpendicular axes. The pores are small, closely spaced, more than eight across a half equator. Some forms in this group tend to a cubic shape.

Hexacontium group B (Plate 1, Fig. 5)

Similar to Hexacontium group A, but having a more robust shell and larger, more separated pores, eight or fewer across the half equator. There are six spines in three mutually perpendicular axes.

\section{Genus Sphaeropyle Dreyer, 1889}

Sphaeropyle langii Dreyer (Plate 1, Fig. 9)

Sphaeropyle langii Dreyer, 1889, p. 13, pl. 4, fig. 54: Kling, 1973, p. 634 , pl. 1 , figs. $5-10$, pl. 13 , figs. $6-8$. 
Table 2. (Continued).

\begin{tabular}{|c|c|c|c|c|c|c|c|c|c|c|c|c|c|c|c|c|c|c|c|c|c|c|c|c|c|c|c|}
\hline 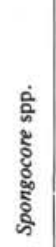 & 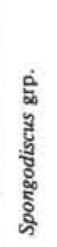 & 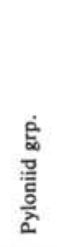 & 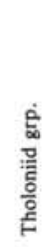 & 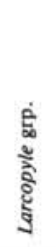 & 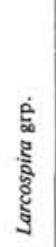 & 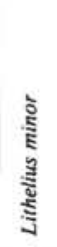 & 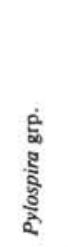 & 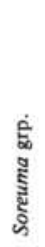 & 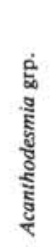 & 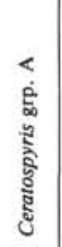 & 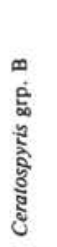 & 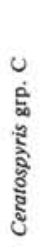 & 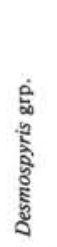 & 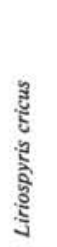 & 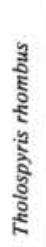 & 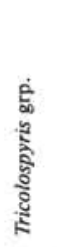 & 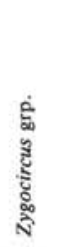 & 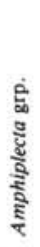 & 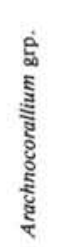 & 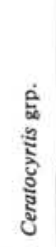 & 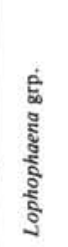 & 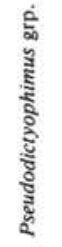 & 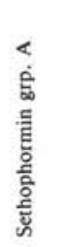 & 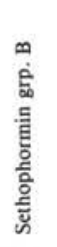 & 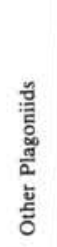 & 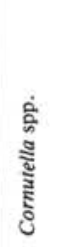 & 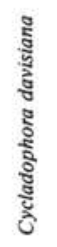 \\
\hline- & 22 & 2.3 & 0.57 & 0.29 & - & 27 & 5.4 & - & - & - & - & - & - & - & - & - & - & - & - & 0.57 & 4.0 & 0.86 & - & - & - & 0.29 & \\
\hline+ & 28 & 1.3 & 0.53 & 0.80 & - & 18 & 8.6 & - & - & 0.80 & - & - & - & - & - & - & - & - & + & 0.53 & 2.4 & + & + & - & - & 1.1 & - \\
\hline 0.75 & 18 & 2.5 & 0.25 & 0.25 & - & 2 & 8.0 & - & - & 1.5 & 0.25 & - & - & - & - & - & - & 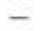 & + & + & 2.5 & + & + & - & - & 2.0 & \\
\hline 0.27 & 4.4 & 0.27 & - & 0.82 & - & 2 & 0.54 & - & - & 0.82 & 0.27 & - & 0.54 & - & - & - & 082 & & - & 1.6 & 0.82 & 0.54 & - & - & 0.27 & 0.27 & \\
\hline- & 7.2 & 0.53 & - & - & - & 4 & 1.1 & - & - & 0 & - & - & - & - & - & - & 53 & - & - & 1.1 & .53 & + & - & 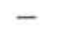 & .27 & & \\
\hline+ & 6.2 & 0.77 & 0.26 & 0. & - & 39 & 3.1 & - & - & 0.52 & - & - & - & - & - & - & + & - & - & + & 5 & + & - & - & - & 0.77 & - \\
\hline+ & 4.2 & + & + & 0.28 & - & 24 & 1.9 & - & - & 0.28 & - & - & 0.28 & - & - & 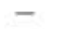 & + & - & - & 0.56 & 4 & + & - & - & - & 0.84 & - \\
\hline- & 3.7 & - & 0.52 & + & - & 15 & 3.7 & - & - & 0.79 & + & - & 0.26 & - & - & - & - & - & - & 0.26 & 0.52 & + & - & - & - & + & - \\
\hline 0.56 & 4.5 & 1.1 & - & 1.1 & - & 32 & 6.8 & - & - & - & - & - & - & - & - & - & - & - & 2.0 & 56 & 1.7 & 3.9 & - & - & - & 1.4 & 9.0 \\
\hline 1.5 & 15 & 0.88 & - & + & - & 17 & 13 & 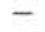 & + & - & - & - & - & - & - & & + & - & + & + & 2.4 & & + & - & + & 0.29 & 12 \\
\hline+ & 15 & 2.9 & + & + & + & 16 & 7.4 & - & - & - & - & - & - & - & - & - & - & - & 0.53 & 0.27 & 2.1 & 0.80 & - & - & - & + & 18 \\
\hline- & 31 & 0.60 & - & + & - & 13 & 6. & - & - & - & - & - & - & - & - & - & - & - & - & 0.30 & 2.4 & 0.60 & - & - & - & 0.30 & 7.8 \\
\hline+ & 18 & + & + & 0.27 & + & 13 & 8.0 & - & + & 0.55 & + & - & - & - & - & + & - & - & 1.4 & 0.82 & 6.6 & - & - & - & - & 6 & + \\
\hline 0.26 & & + & 0.26 & + & 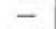 & 25 & 9.1 & - & - & + & 0.26 & 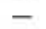 & - & - & - & 0.26 & 0.26 & & + & 0.26 & 2.6 & - & - & & 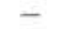 & 0 & - \\
\hline 0.26 & & 2.1 & - & 0.77 & - & 1 & 13 & - & 0.77 & 0.77 & 0.26 & - & - & + & 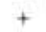 & 26 & + & & 0.51 & 4.1 & 13 & + & 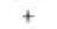 & & + & & - \\
\hline 0.26 & 1 & 0.51 & + & 1. & - & 2 & 9.0 & & + & 0.51 & + & & - & .26 & - & 0.20 & + & & & 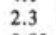 & 6.4 & 0.77 & + & & + & & - \\
\hline & 18 & 0.28 & + & & - & & & - & + & - & - & - & - & - & - & & + & & & & & - & - & & 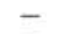 & & 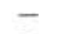 \\
\hline 0.30 & 26 & + & - & 0. & - & 1 & 8.7 & - & + & + & - & - & - & - & - & - & - & & 90 & 0.90 & 3.9 & - & - & - & - & 0.60 & - \\
\hline+ & 24 & 0.26 & - & 0.52 & - & 14 & 4.4 & - & + & 0.78 & + & - & - & - & - & - & + & - & 0.26 & 1.0 & 6.7 & 0.26 & - & - & + & 1.0 & - \\
\hline 0.77 & 7.4 & 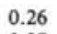 & + & & - & 6.4 & 12 & - & + & 0.77 & - & - & - & - & + & - & + & - & & 5. & 6 & 1.5 & 51 & - & 0.26 & 0.77 & - \\
\hline- & 4.3 & 0.27 & - & 0.80 & - & 35 & 2.9 & - & - & 2.4 & - & - & - & - & - & - & + & - & 1.1 & 2.4 & 4.8 & 0.53 & - & - & - & 1.6 & - \\
\hline- & 4.0 & 0.76 & 0.25 & - & - & 2 & 6.1 & - & - & 0.25 & 0.25 & - & - & & - & - & 0.50 & - & - & 0.76 & 0.76 & - & - & - & - & 0.25 & - \\
\hline+ & 12 & & & 2. & & & & & 0.26 & & & & . & & - & - & & & 0.77 & & 1 & 0.51 & & & - & & $\pi$ \\
\hline 0.49 & 9.7 & & 0.24 & & + & & & & (1. & 0.24 & 0.24 & & - & - & & 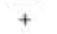 & - & - & - & 1.5 & & 0.73 & 0.24 & - & & & - \\
\hline 0.54 & 15 & 0 & - & & - & & & & - & - & - & & & 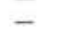 & & & 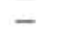 & & - & t & 2 & 0.27 & - & & 0.27 & & - \\
\hline t & & 1. & 0.2 & 1. & - & 1 & & & + & 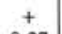 & - & & & & & & & & + & & & - & + & & - & & 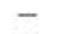 \\
\hline+ & 46 & 1. & - & 0.81 & + & & & & + & 0. & + & & & - & & & & & & & & + & & & & & 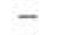 \\
\hline+ & 14 & 2 & 0.2 & + & - & i. & & & - & 0. & . & & - & - & & - & - & & & & & + & - & & - & & - \\
\hline+ & 1. & & + & - & & 1 & & & & & 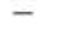 & & + & - & & & + & & & 1.4 & & t & - & & & & - \\
\hline- & 1 & & - & - & & & & & & 0.53 & 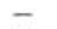 & & + & & & - & - & & & + & & 0.26 & - & & 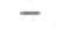 & & - \\
\hline- & 1 & & + & & & & & & & & t & & + & & & - & - & & 1.2 & - & & - & - & & - & & - \\
\hline 0.55 & 20 & & - & & & 32 & & & - & 0.83 & & & 0.28 & & & - & 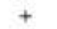 & & + & 0.28 & & + & - & & - & & - \\
\hline & 9.4 & i & - & & & 30 & & & & & & & + & & & 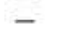 & 0.2 & & - & - & & . & - & & - & & - \\
\hline & . & 1. & 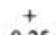 & & & ? & & & & & & & & & & & & & 0.24 & & & 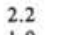 & & & & & - \\
\hline & 1. & 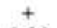 & 0.25 & & & 2 & & & & & & & & & & 0.25 & & & - & & & & & & & & \\
\hline 0.29 & 3 & 0.8 & 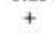 & & - & 3 & & & - & & & - & & & & . & . & & + & + & & & . & & & & 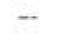 \\
\hline . & 18 & & + & & & 3 & & & & & 0.27 & - & & & & + & 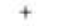 & & - & + & & & - & & 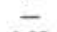 & & \\
\hline & 9. & & - & & & 3 & & - & 0.27 & 0.27 & - & - & 0.80 & - & - & - & 0.53 & & + & 0.53 & & & - & - & 0.27 & & - \\
\hline 0.2 & 7. & & - & & - & 3. & 1. & & & + & 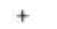 & - & + & 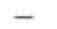 & - & .54 & + & - & + & 0.54 & 0.27 & 0.27 & - & 27 & + & 1.3 & - \\
\hline 0.26 & 7. & 0 & - & 0 & - & 4 & 3. & - & - & 1. & - & - & . & - & - & + & + & - & - & 1.6 & 1.9 & 1.3 & - & 0.26 & 0.26 & 3 & - \\
\hline+ & 8.4 & 1. & - & 1. & - & 21 & 3.3 & - & - & + & 0.26 & - & - & - & - & - & + & - & - & 3.1 & 8 & 1.0 & - & - & 0.51 & 3 & - \\
\hline 0.57 & 13 & 0.85 & 0.28 & 0.57 & + & 22 & 6.5 & - & + & 0.85 & - & - & - & - & - & - & 0.28 & - & + & 1.4 & 4.5 & 0.28 & - & - & - & 0.57 & . \\
\hline
\end{tabular}

Sphaeropyle robusta Kling (Plate 1, Fig. 8)

Sphaeropyle robusta Kling, 1973, p. 634, pl. 1, figs. 11, 12, pl. 6, figs. 9-13, pl. 13, figs. 1-5.

Foreman (1975) used the smaller, more regular pores of the second shell as the distinguishing characteristic between this species and its descendant, $S$. langii. That feature was not apparent in Leg 81 material, so we used Kling's original distinction, namely the robust outer shell of the ancestor.

\section{Genus Stylatractus Haeckel, 1887}

Stylatractus universus Hays (Plate 1, Fig. 7)

Stylatractus universus Hays, 1965, p. 167, pl. 1, fig. 6

Genus Stylosphaera Ehrenberg, 1847a

Stylosphaera goruna Sanfilippo and Riedel (Plate 6, Fig. 11) Stylosphaera goruna Sanfilippo and Riedel, 1973, p. 521, pl. 1, figs. 20-22, pl. 25, figs. 9, 10.

Stylosphaera spp. (Plate 2 Figs. 1A, B)

Bipolar actinommid with spherical medullary shell. Polar spines are usually conical (but not necessarily), usually unequal in length and sometimes not collinear. Specimens with any pore pattern are admitted.

\section{Genus Thecosphaera Haeckel, 1881}

Thecosphaera spp. (Plate 1, Fig. 6)

A regularly spherical cortical shell with no external spines. Six to twelve bars connect the medullary and cortical shells.

Other Actinommids (Plate 2, Figs. 2A-C)

Any actinommid not previously categorized. These usually have numerous spines or no spines, and no medullary shells, or several concentric shells.

Family Phacodiscidae Haeckel, 1881

Phacodiscid group

A lenticular lattice shell with regular pore pattern, enclosing one or more medullary shells and usually having a spiny perimeter.

Family Coccodiscidae Haeckel, 1862, emend. Sanfilippo and Riedel, 1980

Subfamily Artiscinae Haeckel, 1881, emend. Riedel, 1967b

Genus Didymocyrtis Haeckel, 1860b

Didymocyrtis antepenultima (Riedel and Sanfilippo)

Ommatartus antepenultimus Riedel and Sanfilippo, 1970, p. 521, pl. 14, fig. 4: Westberg and Riedel, 1978, p. 22. 
Table 2. (Continued).

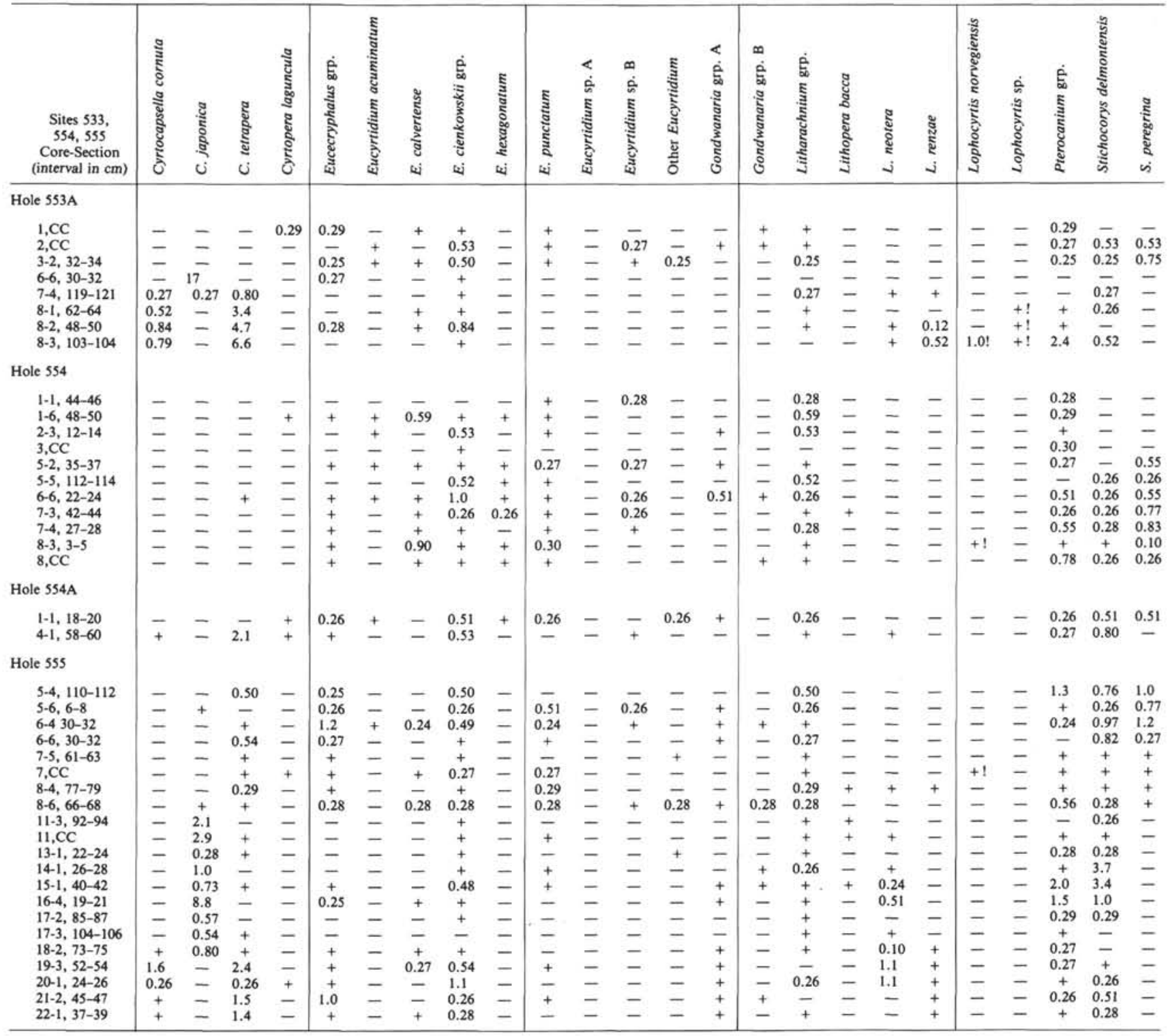

Didymocyrtis antepenultima (Riedel and Sanfilippo)-Sanfilippo and Riedel, 1980, p. 1010.

Didymocyrtis laticonus (Riedel) (Plate 2, Fig. 3)

Cannartus laticonus Riedel, 1959, p. 291, pl. 1, fig. 5: Westberg and Riedel, 1978 , p. 20.

Didymocyrtis laticonus (Riedel)-Sanfilippo and Riedel, 1980, p. 1010.

\section{Didymocyrtis tetrathalamus (Haeckel)}

Panartus tetrathalamus Haeckel, 1887, p. 378, pl. 40, fig. 3.

Ommatartus tetrathalamus (Haeckel)-Riedel and Sanfilippo, 1971 , p. 1558.

Didymocyrtis tetrathalamus (Haeckel)-Sanfilippo and Riedel, 1980 , p. 1010.

Didymocytis spp.

Equatorially constricted cortical shell with a usually lenticular medullary shell. Counted in this group are forms with no extracortical structures.

Genus Diartus Sanfilippo and Riedel, 1980

Diartus petterssoni (Riedel and Sanfilippo)

Cannartus (?) petterssoni Riedel and Sanfilippo, 1970, p. 52, pl. 14 , fig. 3 .
Diartus petterssoni (Riedel and Sanfilippo)-Sanfilippo and Riedel, 1980 , p. 1010.

Family Spongodiscidae Haeckel, 1862, emend. Riedel, 1967b Genus Amphicraspedum Haeckel 1887

Amphicraspedum murrayanum Haeckel

Amphicraspedumn murrayanum Haeckel, 1887, p. 523, pl. 28, fig. 1: Sanfilippo and Riedel, 1973, p. 524, pl. 10, figs. 3-6, pl. 28, fig. 1.

Amphicraspedum prolixum Sanfilippo and Riedel (Plate 6, Fig. 18) Amphicraspedum prolixum Sanfilippo and Riedel, 1973, p. 524, pl. 10, figs. 7-11, pl. 28, figs. 3,4 .

Amphicraspedum prolixum Sanfilippo and Riedel group Amphicraspedum prolixum Sanfilippo and Riedel group, 1973, p. 524 , pl. 11, figs. 1-5, pl. 28, fig. 5 .

Genus Amphymenium Haeckel, 1881

Amphymenium splendiarmatum Clark and Campbell (Plate 6, Fig. 17)

Amphymenium splendiarmatum Clark and Campbell, 1942, p. 46, pl. 1, figs. 12, 14: Sanfilippo and Riedel, 1973, p. 524, pl. 11, figs. 6-8, pl. 28, figs. 6-8. 
Table 2. (Continued).

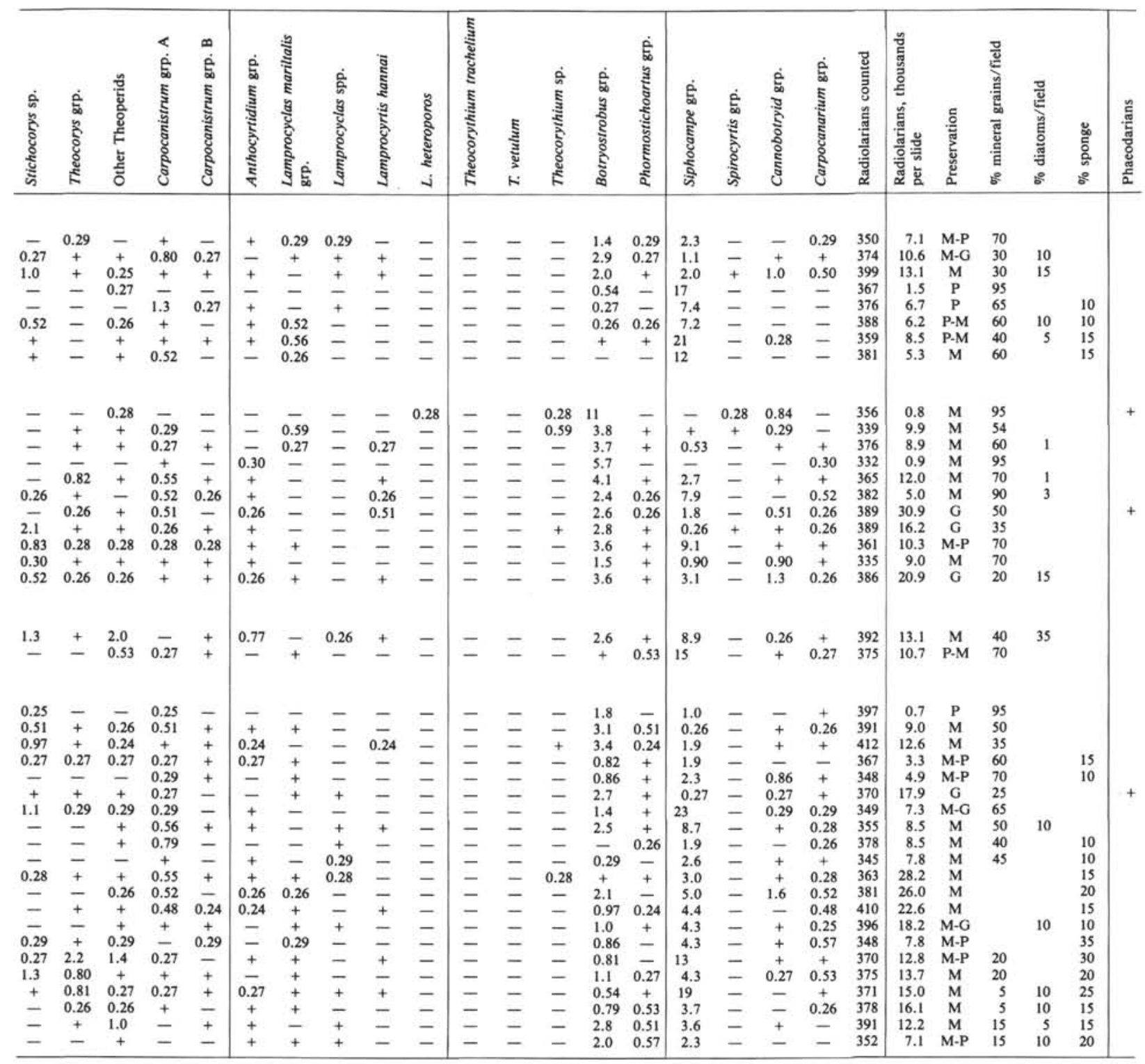

\section{Genus Dictyocoryne Ehrenberg, 1860}

\section{Dictyocoryne group (Plate 3, Fig. 1)}

Triradiate spongodiscids in which concentric structure is absent or completely obscured in the arms, and absent or mostly obscured in the center.

\section{Genus Porodiscus Haeckel, 188}

Porodiscus group A (Pl. 2, Fig. 4)

A simple spongy disc with a variable number of regular or irregular concentric or spiral rings. The concentric structure in the center of the disc is vague or obscured.

Porodiscus group B (Plate 2, Fig. 5)

Similar to Porodiscus group A, but with the concentric structure in the center very distinct and circular. In this group, the rings tend to be more regular, and concentric rather than spiral.

Porodiscus group C (Plate 2, Figs. 8A, B)

This form has very wide concentric (rarely spiral) chambers, no more than four in all. Stöhr's $(1880$, p. 108 , pl. 4 , figs. 16, 17) Trematodiscus ellipticus and T. microporus would be included in this group.

\section{Porodiscids}

In the Eocene tabulation, all discoidal forms with concentric structure were recorded together.

Genus Stylodictya Ehrenberg 1847a, emend. Kozlova in Petrushevskaya and Kozlova 1972

Stylodictya spp. (Plate 2, Fig. 6)

Discoidal porodiscid with round outline and concentric chambers. The innermost chambers are distinctly scalloped.

\section{Genus Spongocore Haeckel, 1887}

Spongocore spp. (Plate 3, Fig. 2)

A cylindrical, bipolar, solid spongy framework having numerous radial beams especially in the center. A veil supported by these beams is sometimes preserved.

\section{Genus Spongodiscus Ehrenberg, 1854}

Spongodiscus group (Plate 2, Figs. 7A, B)

Flat spongy disc, circular to subcircular in outline. For this study, forms with radial spines such as Spongotrochus glacialis Popofsky 1908 
Table 3. Abundances of Eocene radiolarian counting groups at Sites 552 and 553.

\begin{tabular}{|c|c|c|c|c|c|c|c|c|c|c|c|c|c|c|c|}
\hline $\begin{array}{c}\text { Sites } 552 \\
\text { and } 553 \\
\text { Core-Section } \\
\text { (interval in cm) }\end{array}$ & 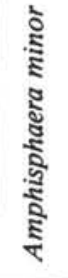 & 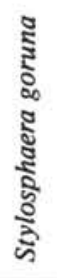 & 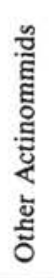 & 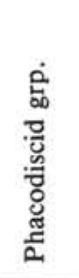 & 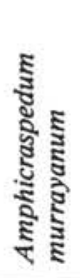 & 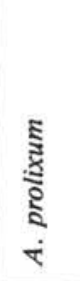 & 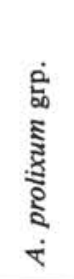 & 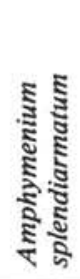 & 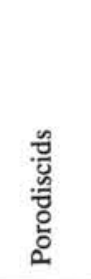 & 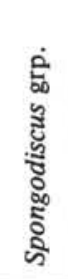 & : & $\begin{array}{l}\text { के } \\
\text { के }\end{array}$ & 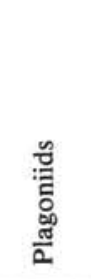 & 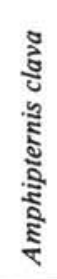 & 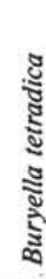 \\
\hline \multicolumn{16}{|l|}{ Hole 552} \\
\hline $\begin{array}{l}10, \mathrm{CC} \\
12-2,37-39 \\
12-4,83-85 \\
12-6,54-56 \\
12-7,33-35 \\
18-2,41-44 \\
21-1,50-52 \\
21-3,47-49\end{array}$ & $\overline{+}$ & + & $\begin{array}{l}45 \\
+ \\
+ \\
+\end{array}$ & - & - & $\begin{array}{l}+ \\
+ \\
+\end{array}$ & $\begin{array}{l}+ \\
+\end{array}$ & - & $\begin{array}{c}0.33 \\
+\end{array}$ & $\begin{array}{l}7.5 \\
+ \\
+ \\
+ \\
+ \\
+ \\
+\end{array}$ & $\begin{array}{l}3.9 \\
+ \\
+ \\
+ \\
+ \\
+ \\
+\end{array}$ & $\begin{array}{c}1.6 \\
+ \\
+\end{array}$ & $\begin{array}{l}2.9 \\
+ \\
+ \\
+\end{array}$ & + & - \\
\hline \multicolumn{16}{|l|}{ Hole $552 \mathrm{~A}$} \\
\hline $\begin{array}{l}37-3,62-63 \\
38-1,120-121 \\
38-2,65-66 \\
38-3,120-121\end{array}$ & $\begin{array}{c}+ \\
0.63 \\
-\overline{0.32}\end{array}$ & $\begin{array}{l}- \\
- \\
-\end{array}$ & $\begin{array}{l}18 \\
38 \\
23 \\
35\end{array}$ & - & $\begin{array}{l}- \\
- \\
-\end{array}$ & $\begin{array}{l}-\overline{32} \\
+ \\
-\end{array}$ & $\begin{array}{c}0.65 \\
- \\
0.33 \\
+\end{array}$ & $\begin{array}{c}- \\
\overline{+} \\
0.97\end{array}$ & $\begin{array}{l}0.32 \\
1.9 \\
1.3 \\
0.65\end{array}$ & $\begin{array}{l}12 \\
20 \\
17 \\
13\end{array}$ & $\begin{array}{c}3.9 \\
11 \\
3.6 \\
14\end{array}$ & $\begin{array}{l}25 \\
3.5 \\
4.6 \\
2.6\end{array}$ & $\begin{array}{c}7.4 \\
6.9 \\
16 \\
5.5\end{array}$ & $\begin{array}{l}- \\
+ \\
+\end{array}$ & $\begin{array}{l}- \\
- \\
-\end{array}$ \\
\hline \multicolumn{16}{|l|}{ Hole $553 \mathrm{~A}$} \\
\hline $\begin{array}{l}10-1,122-124 \\
10-2,122-124 \\
10-5,98-100 \\
11-4,129-131 \\
11-5,82-84\end{array}$ & $\begin{array}{l}0.32 \\
1.6 \\
0.63 \\
+ \\
-\end{array}$ & $\begin{array}{l}- \\
\overline{-} \\
-\end{array}$ & $\begin{array}{l}20 \\
43 \\
31 \\
50 \\
17\end{array}$ & $\begin{array}{l}+ \\
+ \\
+ \\
+ \\
0.63\end{array}$ & $\begin{array}{l}- \\
\overline{-} \\
0.64 \\
0.95\end{array}$ & $\begin{array}{l}- \\
\overline{-} \\
0.96 \\
0.95\end{array}$ & $\begin{array}{l}1.6 \\
\overline{-} \\
2.3 \\
0.63\end{array}$ & $\begin{array}{c}0.32 \\
- \\
0.63 \\
- \\
-\end{array}$ & $\begin{array}{l}11 \\
3.6 \\
1.3 \\
0.64 \\
6.0\end{array}$ & $\begin{array}{l}19 \\
13 \\
3.8 \\
15 \\
25\end{array}$ & $\begin{array}{l}14 \\
12 \\
2.2 \\
18 \\
26\end{array}$ & $\begin{array}{l}3.8 \\
0.97 \\
11 \\
2.6 \\
9.8\end{array}$ & $\begin{array}{l}1.0 \\
+ \\
6.0 \\
0.96 \\
2.5\end{array}$ & $\begin{array}{l}- \\
\overline{+} \\
+\end{array}$ & $\begin{array}{l}- \\
\overline{-} \\
-\end{array}$ \\
\hline
\end{tabular}

Note: Numbers represent abundance in percentage of total radiolarians on the slide as determined by counting the number of individuals indicated on the far right under "Radiolarians counted." "+" indicates $<0.3 \%$ and "- " indicates the group was sought but not found. Where radiolarian density was low or preservation very poor, no counts were made, and in these samples "+" indicates the presence of radiolarian groups. Preservation is shown as M (moderate) or P (poor).

are included in this large group. Any circular flat spongy disc without concentric structure is included here.

Family Pyloniidae Haeckel, 1881

\section{Pyloniid group}

All pyloniids were counted together.

Family Tholoniidae Haeckel, 1887

Tholoniid group

All tholoniids were counted together.

Family Litheliidae Haeckel, 1862

Genus Larcopyle Dreyer, 1889

Larcopyle group (Plate 3, Figs. 3A, B)

The internal spiral structure is enclosed in a smooth elliptical shell with regular outline and small pores. There may be thorns on the outer shell, and there may be a pylome visible at one end which may or may not be surrounded by short spines.

\section{Genus Larcospira Haeckel, 1887}

\section{Larcospira group (Plate 3, Fig. 4)}

The medullary shell is surrounded by an open double spiral, which forms two elongate, subcylindrical wings with their openings in opposite directions. The pore pattern is slightly irregular and the pores tend to increase a little in size toward the distal edge of each wing.

Genus Lithelius Haeckel, 1860a

Lithelius minor Jörgensen (Plate 3, Fig. 5)

Lithelius minor Jörgensen, 1900, p. 65, pl. 5, fig. 24.
Ellipsoidal to subspherical test composed of a single or double spiral, with usually less than five tight, narrow whorls. In some orientations, the spiral structure appears as concentric rings. Pores are small and of nearly equal size, and the shell may be thorny.

\section{Genus Pylospira Haeckel, 1887}

Pylospira group (Plate 3, Figs. 6A, B)

Subspherical to elliptical cortical shell constructed of a single or double spiral, with usually fewer than five loose, wide whorls. The surface of the shell may be thorny, the pores unequal in size and irregular in pattern. This group includes Lithelius nautiloides Popofsky (1908, p. 230, pl. 27, fig. 4).

Family Soreumidae Haeckel, 1881

\section{Genus Soreuma Haeckel, 1881}

Soreuma group (Plate 3, Fig. 7)

Ellipsoidal skeleton of loose spongy mesh. This form resembles some included in the Pylospira group, but the spongy mesh is uniformly disorganized throughout the skeleton, i.e., there is no spiral structure.

Order Nassellaria Ehrenberg, 1875

Suborder Spyrida Ehrenberg, 1847b, emend. Petrushevskaya, 1971

Genus Acanthodesmia Müller, 1857

\section{Acanthodesmia group}

Spyrid consisting of a sagittal ring, a frontal ring, and a basal ring. The bars bear spines which may be quite long and tapered. 
Table 3. (Continued).

\begin{tabular}{|c|c|c|c|c|c|c|c|c|c|c|c|c|c|c|c|c|c|c|}
\hline 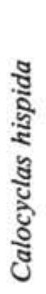 & 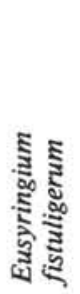 & 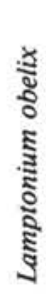 & 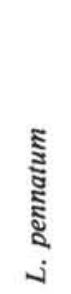 & 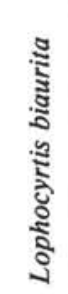 & 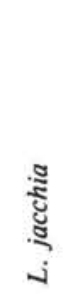 & 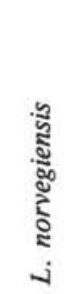 & 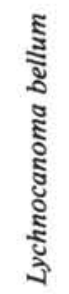 & 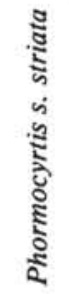 & 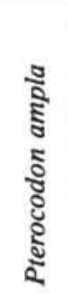 & $\frac{ð}{\stackrel{\Xi}{Q}}$ & 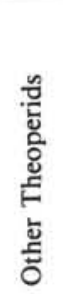 & 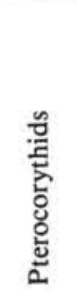 & 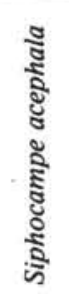 & 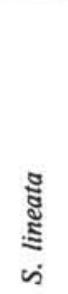 & 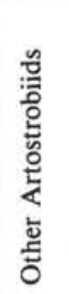 & 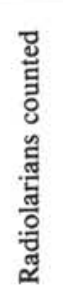 & 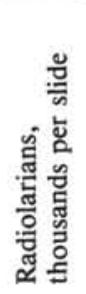 & 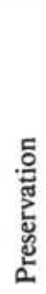 \\
\hline- & - & - & 0.33 & + & - & 25 & - & 1.6 & $\begin{array}{l}11 \\
+ \\
+ \\
+ \\
+ \\
+ \\
+ \\
+\end{array}$ & + & $\begin{array}{l}+ \\
+ \\
+\end{array}$ & - & $\overline{+}$ & - & $\begin{array}{l}+ \\
+\end{array}$ & $\begin{array}{l}307 \\
- \\
- \\
- \\
- \\
- \\
-\end{array}$ & $\begin{aligned} & 6 \\
< & 0.1 \\
< & 0.1 \\
< & 0.1 \\
< & 0.1 \\
& 5 \\
< & 0.5 \\
& 1\end{aligned}$ & $\begin{array}{l}\mathrm{M} \\
\mathrm{M} \\
\mathrm{M} \\
\mathrm{M} \\
\mathrm{M} \\
\mathrm{P} \\
\mathrm{P} \\
\mathrm{P}\end{array}$ \\
\hline- & - & - & - & - & - & + & - & - & 24 & - & 8.4 & + & - & 0.32 & - & 310 & 4 & M \\
\hline- & - & - & 0.32 & - & - & 0.95 & 0.32 & 0.63 & 12 & - & 2.5 & 0.63 & + & - & - & 320 & 2 & M \\
\hline- & - & - & 0.66 & 0.33 & - & 2.6 & 0.33 & - & 11 & - & 15 & 0.66 & 3.3 & + & - & 30 & 6 & M \\
\hline- & - & - & 0.97 & 0.32 & - & 2.6 & - & 0.32 & 5.2 & - & 20 & + & - & + & + & 309 & 5 & M \\
\hline+ & - & - & 0.64 & 6. & + & 6 & + & - & + & - & 8.3 & + & 7.0 & 0.64 & + & 314 & 3 & $\mathrm{M}$ \\
\hline- & + & + & - & 0.65 & 0.97 & 4. & + & - & - & - & 14 & 1.6 & 3.9 & + & + & 3 & 4 & M \\
\hline- & - & - & 0.63 & - & + & 1.9 & - & - & 18 & - & 23 & - & - & 0.32 & 0.63 & 316 & 1 & M \\
\hline- & - & - & - & - & - & - & - & - & 4.8 & 1.3 & 1. & - & 0.64 & - & - & 311 & 9 & M \\
\hline- & - & - & - & - & - & - & - & - & 7.6 & + & 1.9 & - & 0.32 & - & - & 317 & 10 & M \\
\hline
\end{tabular}

Genus Ceratospyris Ehrenberg, 1847a

\section{Ceratospyris group A (Plate 3, Fig. 9)}

Skeleton consisting of a bilocular cephalis without thorns and with any number of feet. In most cases the pores are irregular in size and shape, and the spaces between pores are wide and flat. However, any spyrid with feet, bilocular cephalis and no thorns is included in this counting group.

Ceratospyris group B (Plate 3, Figs. 8A, B)

Bilocular cephalis consisting of large meshes, with no thorax. Short thorns (less than half shell height) may arise from points of intersection of skeletal bars. If feet are present, they are no more developed than these thorns.

\section{Ceratospyris group C (Plate 3, Fig. 10)}

Bilocular cephalis with large paired pores adjoining a distinct sagital constriction. In many specimens there are wide areas between pores. Thorns on the cephalis point away from the basal ring. Feet are more developed than the thorns.

\section{Genus Desmospyris Haeckel, 1881}

\section{Desmospyris group (Plate 3, Figs. 14A, B)}

Bilocular cephalis with a thorax. The sagittal constriction is usually not pronounced, and the pore pattern is similar to that of Ceratospyris group A. However, any spyrid with a thorax and no galea would be included here.

\section{Genus Liriospyris Haeckel 1881, emend. Goll 1968}

Liriospyris cricus Westberg-Smith and Riedel, new species (Plate 3, Figs. 12A-C)

The sagitally constricted lattice shell is attached to a furrowed sagital ring at the front, back, and apex. Generally there are two large pores on the front, four on the back, and a narrow band with two rows of small pores around the sides and top. Two robust bars descend below the basal ring from the front and back of the lattice shell and join to form an oval ring. Measurements based on 10 specimens from Holes 552A and 555: width of lattice shell $121-145 \mu \mathrm{m}$, height of sagittal ring 72-90 $\mu \mathrm{m}$, length of descending ring 63-85 $\mu \mathrm{m}$.

This species is distinguished from all other members of the genus by the robust pendant ring. The specific name is derived from the Greek, krikos, "finger ring," used as a noun in apposition, and alludes to the common use of J. R. R. Tolkien's Hobbit terminology for topographic features in this region.

\section{Genus Tholospyris Haeckel, 1881}

Tholospyris rhombus Haeckel, emend. Goll

Archicircus rhombus Haeckel, 1887, p. 942, pl. 81, fig. 7.

Tholospyris rhombus (Haeckel) emend. Goll, 1972, p. 455, pl. 16, figs. 1-11.

A simple sagittal ring, rhomboid in shape, with four paired spines at the corners.

\section{Genus Tricolospyris Haeckel, 1881}

Tricolospyris group (Plate 3, Fig. 13)

Spyrid consisting of bilocular cephalis, galea, and basket-shaped, closed thorax. The pores are usually irregular in size and shape.

\section{Genus Zygocircus Bütschli, 1882}

Zygocircus group (Plate 3, Fig. 11)

A sagittal ring with no basal ring structures except for rudimentary lateral bars. The entire ring is spiny.

Family Plagoniidae Haeckel, 1881, emend. Riedel, 1967b

$$
\text { Genus Amphiplecta Haeckel, } 1881
$$

\section{Amphiplecta group (Plate 4, Fig, 1)}

Two-segmented plagoniid with cylindrical cephalis having an open top surrounded by thorns. Thorax widely conical. 
Genus Arachnocorallium Haeckel, 1887

Arachnocorallium group (Plate 4, Fig. 2)

One-segmented plagoniid consisting of an ovoid cephalis, the base of which is a narrow structure composed of the median bar and three protruding spines (dorsal and primary laterals).

\section{Genus Ceratocyrtis Bütschli, 1882}

Ceratocyrtis group (Plate 4, Figs. 3A-D)

Two-segmented plagoniid in which the small cephalis is separated from the hood-shaped thorax by a constriction. The conical thorax narrows distally, and pore size usually increases toward the undifferentiated margin.

\section{Genus Lophophaena Ehrenberg, 1847b}

\section{Lophophaena group (Plate 4, Figs. 4A-E)}

This large counting group (any two-segmented plagoniid in which the cephalis and thorax are nearly equal in volume) probably includes several genera. The cephalis is spherical to subspherical, and may or may not have thorns. The thorax is open, conical to cylindrical, and may or may not have appendages. Pores are small, and irregular in size and shape.

\section{Genus Pseudodictyophimus Petrushevskaya, 1971}

Pseudodictyophimus group (Plate 4, Figs. 5A-B)

Two-segmented forms having three thoracic ribs which may extend beyond the margin of the thorax. The cephalis is small and may bear an apical horn. The second segment is usually open, conical to cylindrical, but it may be closed. This group is distinguished by the three thoracic ribs usually extending as feet.

\section{Subfamily Sethophorminae Haeckel, 1881}

Sethophormin group A (Plate 4, Fig. 6)

Widely flattened conical skeleton, with three to four prominent ribs and a distinctly differentiated thoracic rim.

Sethophormin group B (Plate 4, Fig. 7)

Widely flattened conical skeleton with no prominent ribs, nor distinctly differentiated thoracic rim.

Other Plagoniids (Plate 4, Figs. 8A, B)

Any plagoniid which has not been categorized above. Most members of this family encountered in the present material are included in one of the groups described above.

Family Theoperidae Haeckel, 1881, emend. Riedel 1967b

Genus Amphipternis Foreman, 1973

\section{Amphipternis clava (Ehrenberg)}

Lithocampe? clava Ehrenberg, 1873, p. 238.

Amphipternis clava (Ehrenberg)-Foreman, 1973, p. 430, pl. 7, figs. 16, 17, pl. 9, fig. 2 .

Genus Artophormis Haeckel, 1881

Artophormis gracilis Riedel

Artophormis gracilis Riedel, 1959, p. 300, pl. 2, figs. 12, 13.

Genus Buryella Foreman, 1973

\section{Buryella tetradica Foreman}

Buryella tetradica Foreman, 1973, p. 433, pl. 8, figs. 4, 5, pl. 9, figs. 13,14 .

\section{Genus Calocyclas Ehrenberg, 1847b}

\section{Calocyclas hispida (Ehrenberg)}

Anthocyrtis hispida Ehrenberg, 1873, p. 216, pl. 8, fig. 2. Calocyclas hispida (Ehrenberg)-Foreman, 1973, p. 434, pl. 1, figs. 12-15, pl. 9, fig. 18.

\section{Genus Cornutella Ehrenberg, 1838}

\section{Cornutella spp.}

A narrow cone with small cephalis, with or without apical horn. Pores circular to subcircular.
Genus Cycladophora Ehrenberg, 1847a

Cycladophora davisiana Ehrenberg (Plate 4, Fig. 9)

Cycladophora? davisiana Ehrenberg, 1861, p. 297.

Genus Cyrtocapsella Haeckel, 1887

Cyrtocapsella cornuta Haeckel

Cyrtocapsa (Cyrtocapsella) cornuta Haeckel, 1887, p. 1513, pl. 78, fig. 9.

Cyrtocapsella cornuta Haeckel - Sanfilippo and Riedel, 1970, p. 453 , pl. 1, figs. 19-20.

Cyrtocapsella japonica (Nakaseko)

Eusyringium japonicum Nakaseko, 1963, p. 193, text-figs. 20, 21, pl. 4 , figs. 1-3.

Cyrtocapsella japonica (Nakaseko)-Sanfilippo and Riedel, 1970, p. 452 , pl. 1 , figs. $13-15$.

Cyrtocapsella tetrapera Haeckel

Cyrtocapsa (Cyrtocapsella) tetrapera Haeckel, 1887, p. 1512, pl. 78, fig. 5.

Cyrtocapsella tetrapera Haeckel-Sanfilippo and Riedel, 1970, p. 453 , pl. 1 , figs. $16-18$.

\section{Genus Cyrtopera Haeckel, 1881}

Cyrtopera laguncula Haeckel Crytopera laguncula Haeckel, 1887, p. 1451, pl. 75, fig. 10.

Genus Eucecryphalus Haeckel 1860a, emend. Petrushevskaya, 1971

Eucecryphalus grp. (Plate 4, Fig. 10)

This counting group embraces several different forms with three segmented shells forming a wide cone. The abdomen varies from flatly expanded to conical.

Genus Eucyrtidium Ehrenberg 1847a, emend. Nigrini 1967

Eucyrtidium acuminatum (Ehrenberg) (Plate 4, Fig. 11)

Lithocampe acuminatum Ehrenberg, 1844, p. 84

Eucyrtidium acuminatum (Ehrenberg), Nigrini, 1967, p. 81, pl. 8, figs. $3 a, b$.

Multisegmented stichocyrtid with small conical abdomen and lumbar stricture not indented externally.

Eucyrtidium calvertense Martin (Plate 4, Fig. 12)

Eucyrtidium calvertense Martin, 1904, p. 450, 451, pl. 130. fig. 5. Stichocyrtid of five or more segments. There is a distinct change between the second and third segment, and the longitudinally aligned pores are set in deep furrows.

Eucyrtidium cienkowskii Haeckel group, Sanfilippo et al. (Plate 4, Figs. 13A, B)

Eucyrtidium cienkowskii Haeckel, 1887, p. 1493, pl. 80, fig. 9.

Eucyrtidium cienkowskii Haeckel group, Sanfilippo et al., 1973, p. 221, pl. 5, figs. 7-11.

Multisegmented stichocyrtid with small cephalis and thorax set off from the remaining segments by a distinct change in contour; the third segment is conical, the remaining segments cylindrical. Small pores of nearly equal size are aligned in longitudinal rows.

Eucyrtidium hexagonatum Haeckel (Plate 4, Fig. 14)

Eucyrtidium hexagonatum Haeckel, 1887, p. 1489, pl. 80, fig. 11: Nigrini, 1967 , p. 83 , pl. 8 , figs. 4 a, b.

Multisegmented form with small inflated annular thorax set off from lower segments by a distinct lumbar stricture.

Eucyrtidium punctatum (Ehrenberg) group, Sanfilippo et al. (Plate 4, Figs. 15A, B)

Lithocampe punctata Ehrenberg, 1844

Eucyrtidium punctatum (Ehrenberg) group, Sanfilippo et al., 1973, p. 221, pl. 5, figs. 15-16.

Multisegmented stichocyrtid with small cephalis and long conical thorax attaining the same width as the subsequent cylindrical segments. Pores tend to align transversely.

Eucyrtidium sp. A (Plate 5, Fig. 2)

A variant from the $E$. cienkowskii group with a very irregular pore pattern. 
Eucyrtidium sp. B (Plate 5, Fig. 3)

A variant from the $E$. cienkowskii group with thoracic wings and very large pores sometimes quincuncially arranged.

Other Eucyrtidium (Plate 5, Fig. 1)

Any member of the genus which does not fall into one of the above groups.

\section{Genus Eusyringium Haeckel, 1881}

\section{Eusyringium fistuligerum (Ehrenberg)}

Eucyrtidium fistuligerum Ehrenberg, 1873, p. 229.

Eusyringium fistuligerum (Ehrenberg), Haeckel, 1887, p. 1498: Riedel and Sanfilippo, 1970, p. 527, pl. 8, figs. 8, 9.

\section{Genus Gondwanaria Petrushevskaya, 1975}

\section{Gondwanaria group A (Plate 5, Fig. 4)}

A subspherical cephalis, usually with an apical horn, is separated from the cupola-shaped thorax by a distinct constriction. Surface of the thorax is thorny and bears three wings proximally; pores are large, increasing distally and in some specimens decreasing again terminally.

\section{Gondwanaria group B (Plate 5, Fig. 5)}

A spherical cephalis is separated from a cupola-shaped thorax by a distinct constriction; in most specimens a second constriction separates the thorax from a short abdomen. Pores are small, of nearly equal size and irregular pattern. There is a short apical horn, and wing-like ribs protrude from the upper thoracic wall. Includes Lipmanella dictyoceras (Haeckel) (see Kling, 1973, p. 636, pl. 4, figs. 2426).

\section{Genus Lamptonium Haeckel, 1887}

Lamptonium obelix Sanfilippo and Riedel (Plate 6, Fig. 15) Lamptonium obelix Sanfilippo and Riedel, 1979, p. 503, pl. 1, figs. 1,2 .

Lamptonium pennatum Foreman (Plate 6, Fig. 16) Lamptonium pennatum Foreman, 1973, p. 436, pl. 6, figs. 3-5, pl. 11, fig. 13.

\section{Genus Litharachnium Haeckel, 1860a}

\section{Litharachnium group (Plate 5, Fig. 7)}

Two-segmented cone, the pores of which are rectangular or subrectangular. The cephalis is small, the apical horn, if present, rudimentary. Both narrow and more expanded conical forms are included.

\section{Genus Lithopera Ehrenberg, 1847a}

\section{Lithopera bacca Ehrenberg}

Lithopera bacca Ehrenberg, 1872, p. 314; 1873, pl. 8, fig. 1: Sanfilippo and Riedel, 1970, p. 445, pl. 1, fig. 29.

Lithopera neotera Sanfilippo and Riedel

Lithopera neotera Sanfilippo and Riedel, 1970, p. 454, pl. 1, figs. 24-26, 28.

Lithopera renzae Sanfilippo and Riedel

Lithopera (Lithopera) renzae Sanfilippo and Riedel, 1970, p. 454, pl. 1, figs. 21-23, 27.

\section{Genus Lophocyrtis Haeckel, 1887}

Lophocyrtis biaurita (Ehrenberg) (Plate 6, Fig. 13) Eucyrtidium biaurita Ehrenberg, 1873, p. 226. Lophocyrtis biaurita (Ehrenberg)-Foreman, 1973, p. 442, pl. 8 , fig. 23-26.

Lophocyrtis jacchia (Ehrenberg) Thyrsocyrtis jacchia Ehrenberg, 1873, p. 261. Lophocyrtis jacchia (Ehrenberg)-Riedel and Sanfilippo, 1971, p. 1594 , pl. 3 C, fig. 4,5 , pl. 7 , fig. 16 .

Lophocyrtis norvegiensis Bjorklund and Kellogg (Plate 6, Fig. 7) Lophocyrtis norvegiensis Bjørklund and Kellogg, 1972, p. 388, pl. 1 , figs. 2, 7, text-figs. 8,9 .

\section{Lophocyrtis sp.}

Form intermediate between $L$. biaurita and $L$. norvegiensis.

\section{Genus Lychnocanoma Haeckel, 1887}

Lychnocanoma amphitrite (Foreman) (Plate 6, Fig. 14) Lychnocanoma amphitrite Foreman, 1973, p. 437, pl. 11, fig. 10. The specimens here are in the size range described by Foreman (1973), and the feet are short with a stubby, bladed termination; however some specimens have no trace of an abdomen. Although Foreman (1973) reported an evolutionary lower limit for this species in the middle to late Eocene, these specimens and some reported by Sanfilippo and Riedel (1979) from DSDP Leg 48 are from lower to middle Eocene sediments.

\section{Genus Phormocyrtis Haeckel, 1887}

Phormocyrtis striata striata Brandt (Plate 6, Fig. 12)

Phormocyrtis striata striata Brandt (in Wetzel) 1935, p. 55 pl. 9 , fig. 12: Foreman, 1973, p. 438, pl. 7, figs. 5, 6, 9.

Genus Pterocanium Ehrenberg, 1847a

Pterocanium group (Plate 5, Fig. 6)

Three strong, proximally fenestrated feet project from a cupolashaped thorax. Cephalis spherical, small, generally with apical horn. Thoracic pores circular, of nearly equal size and regularly arranged. In well-preserved specimens, there is meshwork between the feet.

\section{Genus Pterocodon Ehrenberg 1847b}

Pterocodon ampla (Brandt) (Plate 6, Fig. 10)

Theocyrtis ampla Brandt (in Wetzel) 1935, p. 56, pl. 9, figs. 13-15. Pterodocon (?) ampla (Brandt)-Foreman, 1973, p. 438, pl. 5, figs. 3-5: Sanfilippo, Westberg-Smith, and Riedel, in press, text-fig. 20-3a.

Specimens of $P$ ampla in this material are larger than those recorded by Foreman (1973) from the Gulf of Mexico, but smaller than Calocyclas talwanii Bjorklund and Kellogg (1972). Dimensions: length excluding horn 158-200 $\mu \mathrm{m}$; length cephalis and thorax 104-149 $\mu \mathrm{m}$; maximum width of thorax 113-158 $\mu \mathrm{m}$; diameter of pores 11-16 $\mu \mathrm{m}$.

Pterocodon lex Sanfilippo and Riedel

Pterocodon lex Sanfilippo and Riedel, 1979, p. 505, pl. 1, figs. 9, 10 .

\section{Genus Stichocorys Haeckel, 1881}

Stichocorys delmontensis (Campbell and Clark) (Plate 5, Fig. 8) Eucyrtidium delmontense Campbell and Clark, 1944, p. 56, pl. 7, figs. 19-20.

Stichocorys delmontensis (Campbell and Clark)-Sanfilippo and Riedel, 1970, p. 451, pl. 1, fig. 9: Sanfilippo, Westberg-Smith and Riedel, in press, text-fig. 23-1a, b.

Stichocorys peregrina (Riedel)

Eucyrtidium peregrinum Riedel, 1953, p. 812, pl. 85, fig. 2.

Stichocorys peregrina (Riedel)-Sanfilippo and Riedel, 1970, p. 451 , pl. 1, fig. 10: Westberg and Riedel, 1978, p. 22, pl. 3, figs. 69: Sanfilippo, Westberg-Smith, and Riedel, in press.

\section{Stichocorys sp.}

This category was used for forms indeterminate because of poor preservation.

\section{Genus Theocorys Haeckel, 1881}

Theocorys group (Plate 5, Fig. 10)

Three-segmented theoperid with open, although sometimes constricted, abdomen without a differentiated termination. Small, spherical cephalis bears a small apical horn. Pores are subcircular, of nearly equal size on both abdomen and thorax.

Other Theoperids (Plate 5, Fig. 9)

Any theoperid not accounted for in one of the preceding counting groups.

\section{Family Carpocaniidae Haeckel 1881, emend. Riedel, 1967b}

Genus Carpocanistrum Haeckel, 1887

Carpocanistrum group A (Plate 5, Figs. 11A, B)

Two-segmented form, the cephalis of which is merged into the upper thorax. The thoracic opening is constricted, usually with a wide 
peristome and sometimes peristomial teeth. Pores are circular, of nearly equal size, and aligned longitudinally. There may be ridges between pore rows, and the outline is always smooth.

Carpocanistrum group B (Plate 5, Fig. 12)

Form similar to Carpocanistrum group A in all respects except that the surface of the shell is rough.

Family Pterocorythidae Haeckel 1881, emend. Riedel, 1967b

Genus Anthocyrtidium Haeckel, 1881

Anthocyrtidium group (Plate 5, Fig. 15)

This group includes all two-segmented pterocorythids. The thorax varies in the degree of inflation, and terminal teeth vary markedly in their degree of development. There is usually a stout, bladed apical horn, and subcircular pores are of nearly equal size and regularly arranged.

Genus Lamprocyclas Haeckel, 1887

Lamprocyclas maritalis Haeckel group (Plate 5, Fig. 13)

Lamprocyclas maritalis Haeckel, 1887, p. 1390, pl. 74, figs. 13, 14. Lamprocyclas maritalis maritalis Haeckel, Nigrini, 1967, p. 74, pl. 7 , fig. 5 .

Lamprocyclas maritalis Haeckel polypora Nigrini, 1967, p. 76, pl. 7, fig. 6.

Lamprocyclas spp.

In this category are forms similar to $L$. maritalis grp., Theocorythium vetulum or Lamprocyrtis hannai, but not conforming exactly to their descriptions.

\section{Genus Lamprocyrtis Kling, 1973}

Lamprocyrtis (?) hannai (Campbell and Clark) (Plate 5, Fig. 14A, B) Calocyclas hannai Campbell and Clark, 1944, p. 48, pl. 69, figs. 21, 22.

Lamprocyrtis (?) hannai (Campbell and Clark)-Kling, 1973, p. 638 , pl. 5, figs. 12-14, pl. 12, figs. 10-14.

Lamprocyrtis heteroporos (Hays)

Lamprocyclas heteroporos Hays, 1965, p. 179, pl. 3, fig. 1. Lamprocyrtis heteroporos (Hays) -Kling, 1973, p. 639, pl. 5, figs. $19-21$, pl. 15 , fig. 6 .

\section{Genus Theocorythium Haeckel, 1887}

Theocorythium trachelium (Ehrenberg) dianae (Haeckel) (Plate 5, Fig. 16).

Eucyrtidium trachelius Ehrenberg, 1872, p. 312.

Theocorys dianae Haeckel, 1887, p. 1416, pl. 69, fig. 11.

Theocorythium trachelium (Ehrenberg) dianae (Haeckel)-Nigrini, 1967 , p. 77 , pl. 8 , figs. 1a, b, pl. 9 , figs. 1a, b.

Theocorythium vetulum Nigrini (Plate 5, Fig. 17)

Theocorythium vetulum Nigrini, 1971, p. 447, pl. 34.1, figs. 6a, b.

Family Artostrobiidae Riedel, 1967a

Genus Botryostrobus Haeckel 1887, emend. Nigrini, 1977

Botryostrobus group (Plate 6, Figs. 1A, B)

Shell with more than four segments, each with three or more transverse rows of small pores, and separated by deep constrictions. Cephalis bears an apical horn and cylindrical vertical tube. Outline of each segment is smooth and rounded.

Genus Phormostichoartus Campbell, 1951, emend. Nigrini, 1977

Phormostichoartus group (Plate 6, Figs. 2A, B)

Cylindrical shell with four segments, and many rows of small, transversely aligned pores on third and fourth segments. There is no apical horn, and a well-developed, cyindrical vertical tube lies along the proximal thorax.

Genus Siphocampe Haeckel, 1881, emend. Nigrini, 1977

Siphocampe acephala (Ehrenberg)

Eucyrtidium acephalum Ehrenberg, 1875, p. 70, pl. 11, fig. 5 Siphocampe acephala (Ehrenberg)-Nigrini, 1977, p. 255, pl. 3, fig. 5 .
Siphocampe lineata (Ehrenberg) group

Lithocampe lineata Ehrenberg, 1838, p. 130.

Siphocampe lineta (Ehrenberg) group-Nigrini, 1977, p. 256, pl. 3 , figs. 9,10 .

Siphocampe group (Plate 6, Fig. 3)

In the Neogene samples, all three-segmented artostrobiids having a short vertical tube, no horn, and widely separated transverse rows of small pores were counted together in this group.

Genus Spirocyrtis Haeckel, 1881, emend. Nigrini, 1977

Spirocyrtis group (Plate 6, Fig. 4)

Multisegmented artostrobiid with prominent flared (duck-billed) vertical tube and apical horn. Segments with angular constrictions expand distally, and each bears several transverse rows of pores. The most obvious character in this group is the stepped profile produced by the angular constrictions.

Family Cannobotryidae Haeckel, emend. Riedel, 1967b

Cannobotryid group (Plate 6, Fig. 6)

Two- or three-segmented forms with very large cephalis composed of at least three chambers, one or two of which may be elongated into tubes. This complicated cephalic structure may be as large as, or larger than, the cylindrical thorax. Pores are small, and irregular in size and arrangement.

Incertae sedis

Genus Carpocanarium Haeckel, 1887

Carpocanarium group (Plate 6, Fig. 5)

Two-segmented form with hemispherical cephalis separated from an ovate thorax by a well-defined stricture. Sometimes a small lateral cephalic tube is observed, and in some specimens there are three small, wing-like thoracic ribs. Pores are widely spaced, of nearly equal size.

\section{ACKNOWLEDGMENTS}

Financial support for this study was provided by National Science Foundation Grant No. OCE81-17346. Annika Sanfilippo assisted with Eocene determinations, and Marilyn Orona competently typed the manuscript and assisted in proofreading.

\section{REFERENCES}

Benson, R. N., 1966. Recent radiolaria from the Gulf of California [Ph.D. thesis]. Minnesota University, Minneapolis, Minnesota.

Bjørklund, K. R., 1976. Radiolaria from the Norwegian Sea, Leg 38 of the Deep Sea Drilling Project. In Talwani, M., Udintsev, G., et al., Init. Repts. DSDP, 38: Washington (U.S. Govt. Printing Office), 1101-1168.

Bjørklund, K. R., and Kellogg, D. E., 1972. Five new Eocene radiolarian species from the Norwegian Sea. Micropaleontology, 18(3): 386-396.

Brandt, R., 1935. Radiolaria. In Wetzel, E. O. (Ed.), Die Mikropaleontologie des Heiligenhafener Kieseltones (Ober-Eözan): Hannover (Jahresbericht des Niedersächsischen geologischen Vereins), pp. 41-81.

Bütschli, O., 1882. Beiträge zur Kenntnis der Radiolarienskelette, insbesondere der der Cyrtida. Z. Wissen. Zool., 36:485-540.

Campbell, A. S., 1951. New genera and subgenera of Radiolaria. $J$. Paleontol., 25(4):527-530.

Campbell, A. S., and Clark, B. L., 1944. Miocene radiolarian faunas from southern California. Geol. Soc. Am., Spec. Pap. 51:1-76.

Clark, B. L., and Campbell, A. S., 1942. Eocene radiolarian faunas from the Monte Diablo area, California. Geol. Soc. Am., Spec. Pap. 39:1-112.

Dreyer, F., 1889. Die pylombildungen in vergleichendanatomischer und entwicklungs-geschichtlicher Beziehung bei Radiolarien und bei Protisten überhaupt. J. Z. Naturwiss., 23:1-138.

Dumitricà, P., 1973. Cretaceous and Quaternary Radiolaria in deep sea sediments from the northeast Atlantic Ocean and Mediterranean Sea. In Ryan, W. B. F., Hsü, K. J., et al., Init. Repts. DSDP, 13, Pt. 2: Washington (U.S. Govt. Printing Office), 829-901.

Ehrenberg, C. G., 1838. Über die Bildung der Kreidefelsen und des Kreidemergels durch unsichtbare Organismen. K. Akad. Wiss. Berlin, Abh., pp. 59-147. pls. 1-4. 
1844. Über 2 neue Lager von Gebirgsmassen aus Infusorien als Meeres-Absatz in Nord-Amerika und eine Vergleichung derselben mit den organischen Kreide-Gebilden in Europa und Afrika. K. Preuss. Akad. Wiss, Berlin, Ber., pp. 57-97.

1847a. Über eine halibiolithische, von Herrn R. Schomburgk entdeckte, vorherrschend aus mikroskopischen Polycystinen gebildete, Gebirgsmasse von Barbados. K. Preuss. Akad. Wiss. Berlin, Ber., pp. 382-385.

1847b. Über die mikroskopischen kieselschaligen Polycystinen als mächtige Gebirgsmasse von Barbados und über das Verhältniss der aus mehr als 300 neuen Arten bestehenden ganz eigenthümlichen Formengruppe jener Felsmasse zu den jetzt legenden Thieren und zur Kreidebildung. Einen eue Anregung zur Erforschung des Erdlebens. K. Preuss. Akad. Wiss. Berlin, Ber., pp. 40-60. 1854. Die systematische Charakteristik der neuen mikroskopischen Organismen des tiefen atlantischen Oceans. $K$. Preuss. Akad. Wiss. Berlin Ber., pp. 236-250.

1860. Über den Tiefgrund des stillen Oceans zwischen Californien und den Sandwich-Inseln aus bis $15600^{\prime}$ Tiefe nach Lieutenant Brooke. K. Preuss. Akad. Wiss. Berlin, Monatsber., pp. 819-833.

, 1861. Über die Tiefgrund-Verhältnisse des Oceans am Einegange der Davisstrasse und bei Island. K. Preuss. Akad. Wiss. Berlin, Monatsber., pp. 275-315.

1872. Mikrogeologische Studien als Zusammenfassung der Beobachtungen des kleinsten Lebens der Meeres-Tiefgründe aller Zonen und dessen geologischen Einfluss. K. Preuss. Akad. Wiss. Berlin, Monatsber., pp. 265-322.

1873. Grössere Felsproben des Polycystinen-Mergels von Barbados mit weiteren Erläuterungen. K. Preuss. Akad. Wiss. Berlin, Monatsber., pp. 213-263.

1875. Fortsetzung der mikrogeologischen Studien als Gesammt-Uebersicht der mikroskopischen Pälaontologie gleichartig analysirter Gebirgsarten der Erde, mit specieller Rücksicht auf den Polycystinen-Mergel von Barbados. K. Preuss. Akad. Wiss. Berlin, Abh., pp. 1-225.

Foreman, H. P., 1973. Radiolaria of Leg 10 with systematics and ranges for the families Amphipyn dacidae, Artostrobiidae, and Theoperidae. In Worzel, J. L., Bryant, W., et al., Init. Repts. DSDP, 10: Washington (U.S. Govt. Printing Office), 407-474.

1975. Radiolaria from the North Pacific, Deep Sea Drilling Project, Leg 32. In Larson, R. L., Moberly, R., et al., Init. Repts. DSDP, 32: Washington (U.S. Govt. Printing Office), 579-676.

Goll, R. M., 1968. Classification and phylogeny of Cenozoic Trissocyclidae (Radiolaria) in the Pacific and Caribbean Basins. Part I. J. Paleontol., 42(6): 1409-1432.

1972. Systematics of eight Tholospyris taxa (Trissocyclidae, Radiolaria). Micropaleontology, 18(4):443-475.

Haeckel, E., 1860a. Fernere Abbildungen und Diagnosen neuer Gattungen und Arten von lebenden Radiolarien des Mittelmeeres. $K$. Preuss. Akad. Wiss. Berlin, Monatsber., pp. 835-845.

1860b. Über neue, lebende Radiolarien des Mittelmeeres. K. Preuss. Akad. Wiss. Berlin, Monatsber., pp. 794-817.

, 1862. Die Radiolarien (Rhizopoda Radiolaria): Berlin (Reimer).

, 1881. Entwurf eines Radiolarien-Systems auf Grund von Studien der Challenger-Radiolarien. J. Z. Naturwiss., 15:418-472. 1887. Report on the Radiolaria collected by H. M. S. Challenger during the years 1873-1876. Report on the Scientific Results of the Voyage of the H.M.S. Challenger. Zoology, 18.

Hays, J. D., 1965. Radiolaria and late Tertiary and Quaternary history of Antarctic Seas. Biology of Antarctic Seas II. Am. Geophys. Union, Antarctic Res. Ser. 5:125-184.

Hollande, A., and Enjumet, M., 1960. Cytologie, évolution et systématique des Sphaeroidés (Radiolaires). Arch. Mus. Nat. Hist. Naturelle, Paris, 7:1-134.

Jörgensen, E., 1900. Protophyten und Protozöen im Plankton aus der norwegischen Westkuste. Bergens Mus. Aarbog, pp. 1-112.

Kling, S, A., 1973. Radiolaria from the eastern North Pacific, Deep Sea Drilling Project Leg 18. In Kulm, L. D., von Huene, R., et al., Init. Repts. DSDP, 18: Washington (U.S. Govt. Printing Office), 617-671.

Loeblich, A. R., and Tappan, H., 1961. Remarks on the systematics of the Sarkodina (Protozoa), renamed homonyms and new validated genera. Proc. Biol. Soc. Washington, 74:213-234.
Martin, G. C., 1904. Radiolaria. Baltimore (Maryland Geological Survey, (The Johns Hopkins Press), pp. 447-459.

Mast, H., 1910. Die Astrosphaeriden der Deutschen Tiefsee-Expedition [dissert.]. Universität Tübingen.

Müller, J., 1857. Über die Thalassicollen, Polycystinen und Acanthometren des Mittelmeeres. K. Preuss. Akad. Wiss. Berlin, Monatsber., pp. 474-503.

1858. Über die Thalassicollen, Polycystinen und Acanthometren des Mittelmeeres. K. Preuss. Akad. Wiss. Berlin, Abh., pp. 1-62.

Nakaseko, K., 1963. Neogene Cyrtoidea (Radiolaria) from the Isozaki Formation in Ibaraki, Prefecture, Japan. Sci. Rep., College of General Education, Osaka University, 12(2):165-198.

Nigrini, C. A. 1967. Radiolaria in pelagic sediments from the Indian and Atlantic Oceans. SIO Bull., 11:1-125.

1971. Radiolarian zones in the Quaternary of the equatorial Pacific Ocean. In Funnell, B. M., and Riedel, W. R., (Eds), The Micropalaeontology of Oceans: Cambridge (Cambridge University Press), pp. 443-461.

1977. Tropical Cenozoic Artostrobiidae (Radiolaria). Micropaleontology, 23(3):241-269.

Petrushevskaya, M. G., 1971. On the natural system of polycystine Radiolaria (Class Sarcodina). In Farinacci, A. (Ed.), Proc. 2nd Plank. Conf., Rome, (Tecnoscienza) pp. 981-982.

1975. Cenozoic radiolarians of the Antarctic, Leg 29 DSDP. In Kennett, J. P., Houtz, R. E., et al., Init. Repts. DSDP, 29: Washington (U.S. Govt. Printing Office), 541-675.

Petrushevskaya, M. G., and Kozlova, G. E. 1972. Radiolaria: Leg 14, Deep Sea Drilling Project. In Hayes, D. E., Pimm, A. C., et al., Init. Repts. DSDP, 14: Washington (U.S. Govt. Printing Office), 495-648.

Popofsky, A., 1908. Die Radiolarien der Antarktis (mit Ausnahme der Tripyleen). Deutsche Sudpolar-Exped. 1901-1903, 10:183-305.

Riedel, W. R., 1953. Mesozoic and late Tertiary Radiolaria of Rotti. J. Paleontol., 27(6):805-813.

1959. Oligocene and Lower Miocene Radiolaria in tropical Pacific sediments. Micropaleontology, 5(3):285-302.

1967a. Some new families of Radiolaria. Proc. Geol. Soc. London, 1640:148-149.

1967b. Subclass Radiolaria. In Harland, W. B., et al (Eds.), The Fossil Record: London (Geological Society of London), pp. 291-298.

Riedel, W. R., and Sanfilippo, A., 1970. Radiolaria, Leg 4, Deep Sea Drilling Project. In Bader, R. C., Gerard, R. D., et al., Init. Repts. DSDP, 4: Washington (U.S. Govt. Printing Office), 503-575. 1971. Cenozoic Radiolaria from the western tropical Pacific, Leg 7. In Winterer, E. L., Riedel, W. R., et al., Init. Repts. DSDP, 7: Washington (U.S. Govt. Printing Office), 1529-1672. 1978. Stratigraphy and evolution of tropical Cenozoic radiolarians. Micropaleontology, 24(1): 61-96.

Sanfilippo, A., Burckle, L. H., Martini, E., and Riedel, W. R., 1973. Radiolarians, diatoms, silicoflagellates and calcareous nannofossils in the Mediterranean Neogene. Micropaleontology, 19(2): 209-234.

Sanfilippo, A., and Riedel, W. R., 1970. Post-Eocene "closed" theoperid radiolarians. Micropaleontology, 16(4):446-462.

1973. Cenozoic Radiolaria (exclusive of theoperids, artostrobiids and amphipyndacids) from the Gulf of Mexico, DSDP Leg 10. In Worzel, J. L., Bryant, W., et al., Init. Repts. DSDP, 10: Washington (U.S. Govt. Printing Office),457-611.

1979. Radiolaria from the northeastern Atlantic Ocean, DSDP Leg 48. In Montadert, L., Roberts, D. G., et al., Init. Repts. DSDP, 48: Washington (U.S. Govt. Printing Office), 493-511.

1980. A revised generic and suprageneric classification of the Artiscins (Radiolaria). J. Paleontol., 54(5):1008-1011.

Sanfilippo, A., Westberg-Smith, J., and Riedel, W. R., in press. Cenozoic Radiolaria. In Bolli, H. M., Perch-Nielsen, K., and Saunders, J. B., (Eds.), Biostratigraphy by Marine Plankton: Cambridge (Cambridge University Press).

Stöhr, E., 1880. Die Radiolarienfauna der Tripoli von Grotte, Provinz Girgenti in Sicilien. Palaeontographica, 26:71-124.

Westberg, M. J., and Riedel, W. R., 1978. Accuracy of radiolarian correlations in the Pacific Miocene. Micropaleontology, 24(1):1-23.

Date of Acceptance: July 8, 1983 


\section{NOTE TO PLATES}

In the explanations to the figures, the sample numbers and slide designations (in the form "Sl.1" "Ph.1," etc.) indicate preparations in our collection at Scripps Institution of Oceanography; designations in the form "L25/1" indicate England Finder positions of the illustrated specimens on the slides.
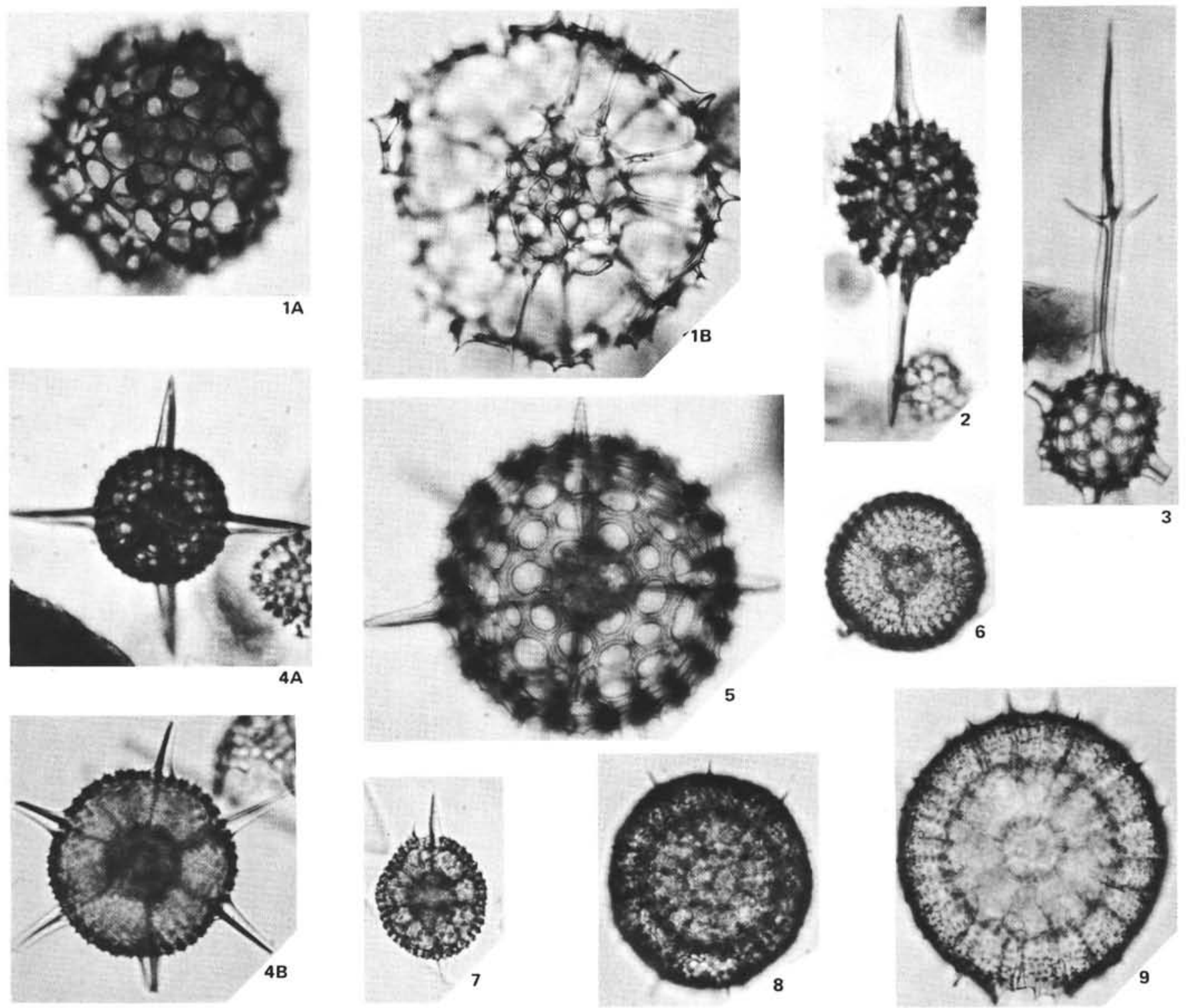

Plate 1. Radiolarians, $230 \times$. 1. Actinomma medianum; (A) Sample 552-12-1, 95-97 cm, Sl.2, V17/0; (B) Sample 552A-12-1, 95-97 cm, Sl. 2, K30/4. 2. Druppatractus group, Sample 552-5,CC, Sl. 2, B19/0. 3. Anomalacantha dentata: Sample 552A-1,CC, Sl. 2, C13/4. 4. Hexacontium group A, (A) Sample 555-15-1, 40-42 cm, Sl. 1, E18/1; (B) Sample 552-4-2, 91-93 cm, Sl.1, C11/1. 5. Hexacontium group B: Sample 552A-1,CC, Cs.2, K12/0. 6. Thecosphaera spp.: Sample 552-5,CC, Sl.1, V22/1. 7. Stylatractus universus: Sample 552-3-3, 70-72 cm, Ph. 2, J18/1. 8. Sphaeropyle robusta: Sample 552A-26-1, 65-66 cm, Sl.1, N21/1. 9. Sphaeropyle langii: Sample 552A-14-1, 30-31 cm, Sl. 1, C25/2. 

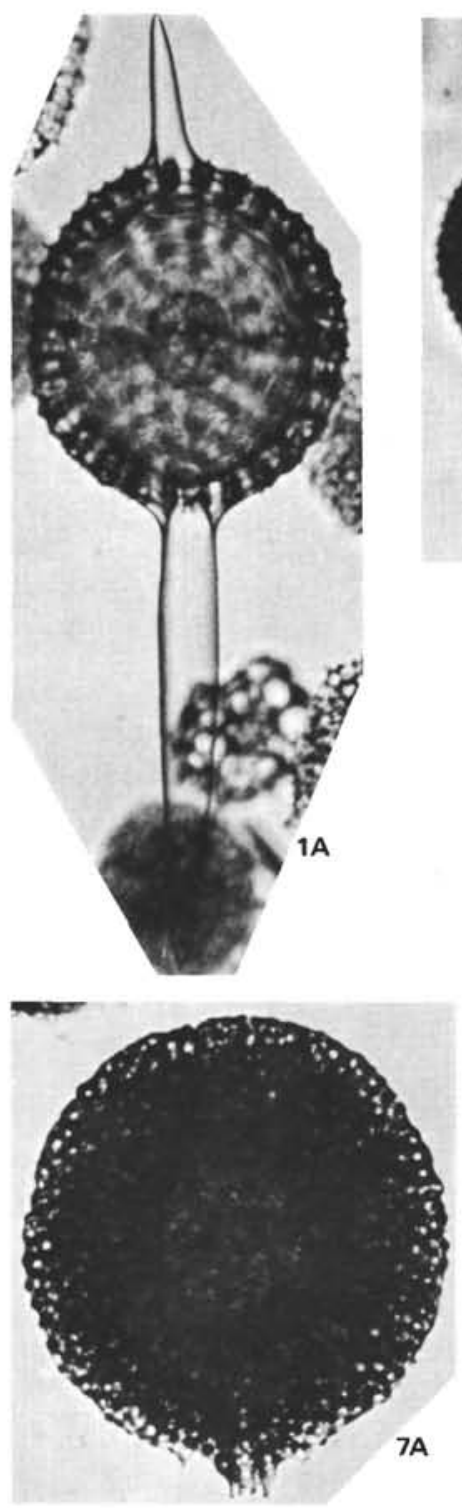
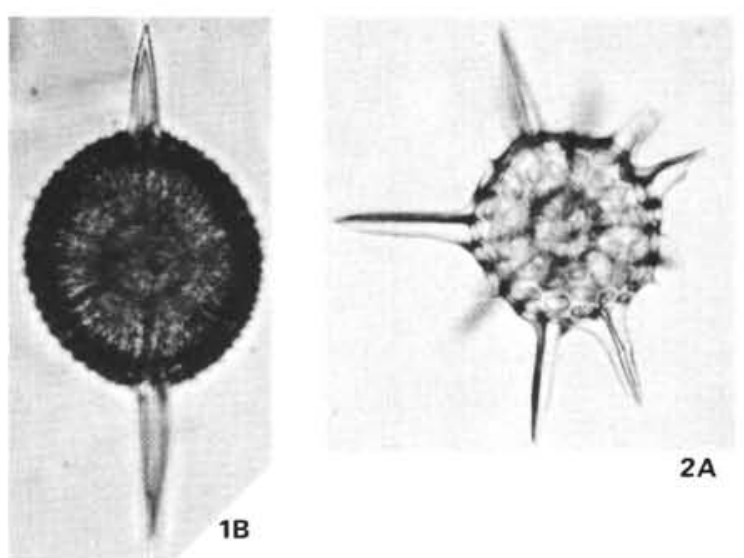

2A
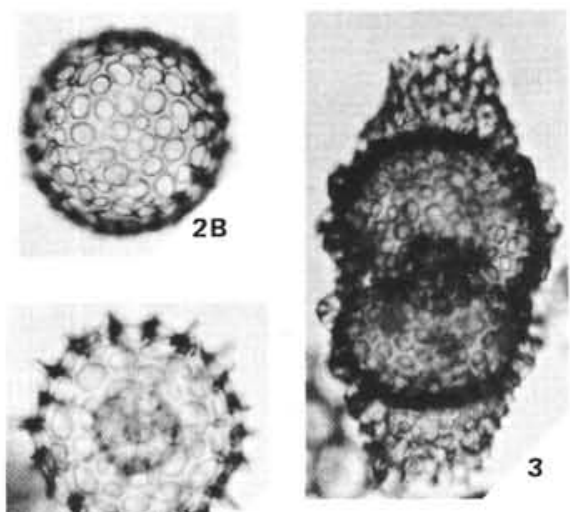

2C

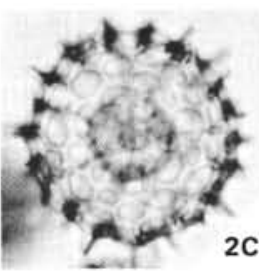

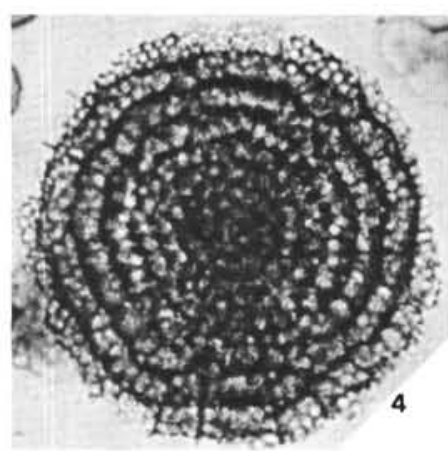
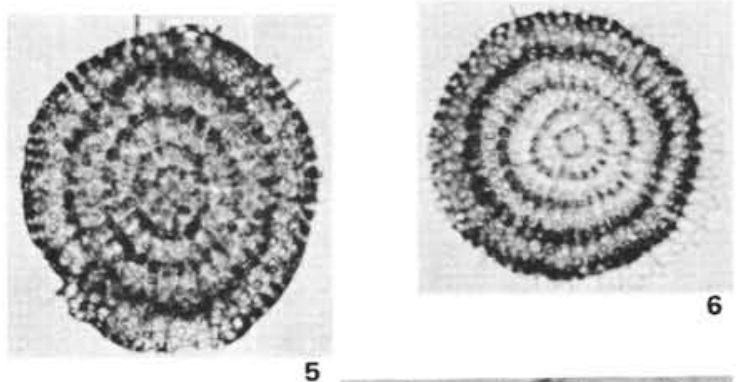

5

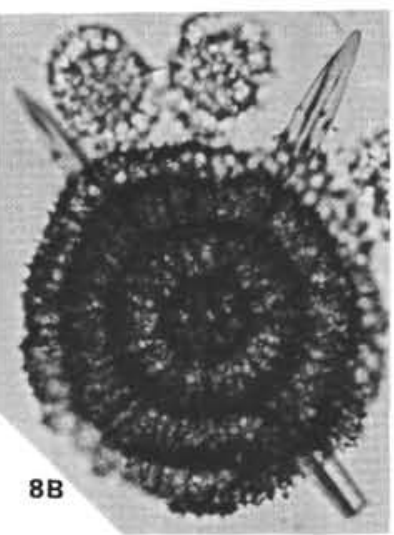

Plate 2. Radiolarians, $230 \times$. 1. Stylosphaera spp., (A) Sample 555-15-1, 40-42 cm, Sl.1, F31/1; (B) Sample 552-3-3, 70-72 cm, Ph. $2, \mathrm{M} 35 / 3$. 2. Other Actinommids, (A) Sample 552A-1,CC, Sl.2, R39/1; (B) Sample 552A-1,CC, Sl.2, Q26/3; (C) Sample 552A-1,CC, Sl.2, R16/1. 3. Didymocyrtis laticonus: Sample 555-15-1, 40-42 cm, Sl.1, G28/4. 4. Porodiscus group A: Sample 552-4-2, 91-93 cm, S1.1, S9/3. 5. Porodiscus group B: Sample 552A-1,CC, Sl.2, R6/2. 6. Stylodictya spp.: Sample 552A-19,CC, Sl.2, T19/0. 7. Spongodiscus group, (A) Sample 552-4-2, 91-93 cm, Sl.1, P12/3; (B) Sample 552A-1,CC, Sl.2, R37/1. 8. Porodiscus group C, (A) Sample 555-15-1, 40-42 cm, Sl. 1, E10/3; (B) Sample $552 \mathrm{~A}-16-1,134-135 \mathrm{~cm}, \mathrm{Sl} .2, \mathrm{P} 38 / 4$. 

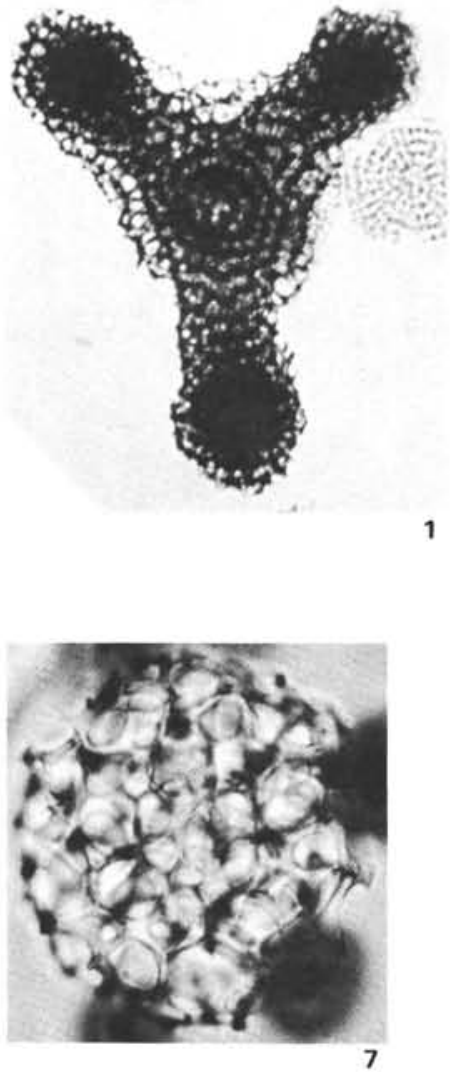
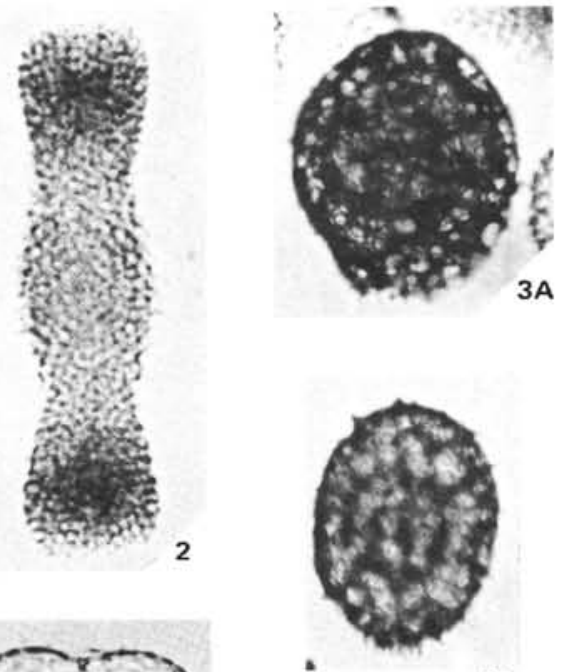

3B
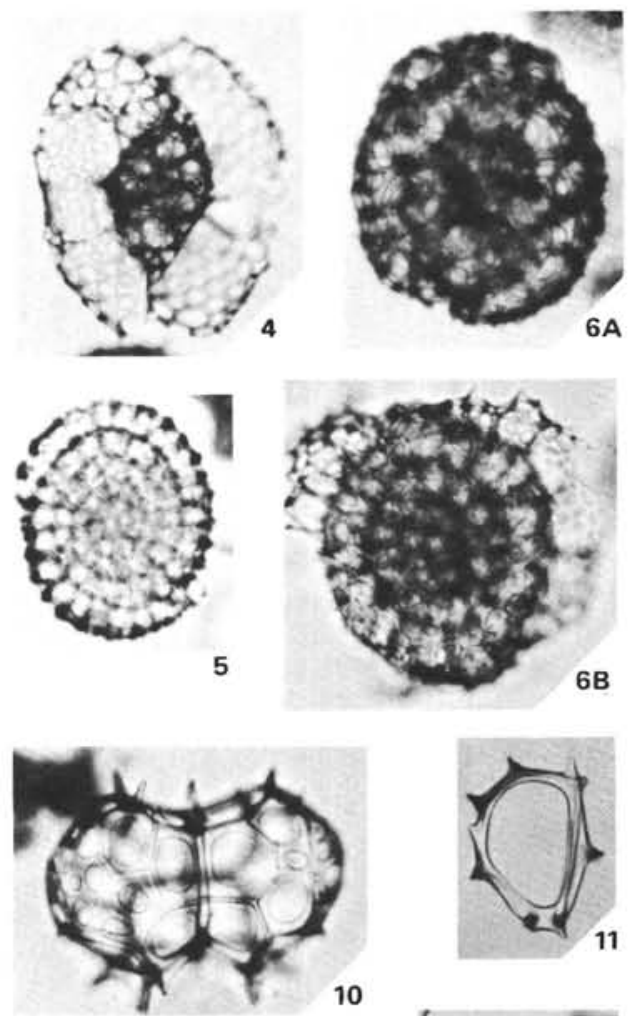

9
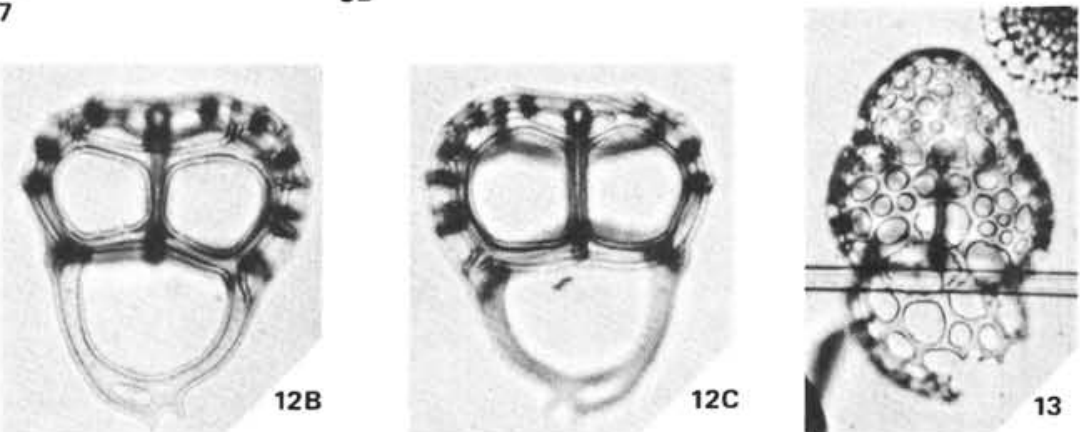

Plate 3. Radiolarians, $230 \times$. 1. Dictyocoryne group: Sample 552-4-2, 91-93 cm, Sl.1, M11/0. 2. Spongocore spp: Sample 552A-14-3, 11-12 cm, Sl.1, P23/3. 3. Larcopyle group, (A) Sample 552A-14-3, 11-12 cm, Sl.1, N32/1; (B) Sample 552A-1,CC, Sl.2, W35/1. 4. Larcospira group: Sample 552A-19,CC, Ph. 1, K46/4. 5. Lithelius minor: Sample 552-3-3, 70-72 cm, Ph. 2, J29/3. 6. Pylospira group, (A) Sample 552-3-3, 70-72 cm, Ph. 2, J18/0; (B) Sample 552-3,CC, Sl.1, Q17/0. 7. Soreuma group: Sample 552A-1-3, 53-54 cm, Sl.2, L13/1. 8. Ceratospyris group B, (A) Sample 554-6-6, 22-24 cm, Sl.2, C40/3; (B) Sample 555-5-6, 6-8 cm, Sl.2, K21/2. 9. Ceratospyris group A: Sample 552A-14-3, 11-12 cm, Sl.1, A14/3. 10. Ceratospyris group C: Sample 555-15-1, 40-42 cm Sl.1, O9/0. 11. Zygocircus group: Sample 555-19-3, 52-54 cm, Sl.1, U4/4. 12. Liriospyris cricus, (A) Sample 552-4-2, 91-93 cm, Sl.1, K14/2; (B, C) Holotype (B, back view; C, front view), Sample 552A27-1, 108-109 cm, Ph. 2, L14/0. 13. Tricolospyris group: Sample 555-15-1, 40-42 cm, Sl.1, J15/2. 14. Desmospyris group, (A) Sample 55517-1, 44-46 cm, Sl.2, R12/1; (B) Sample 554-6-6, 22-24 cm, Sl.2, W27/0. 

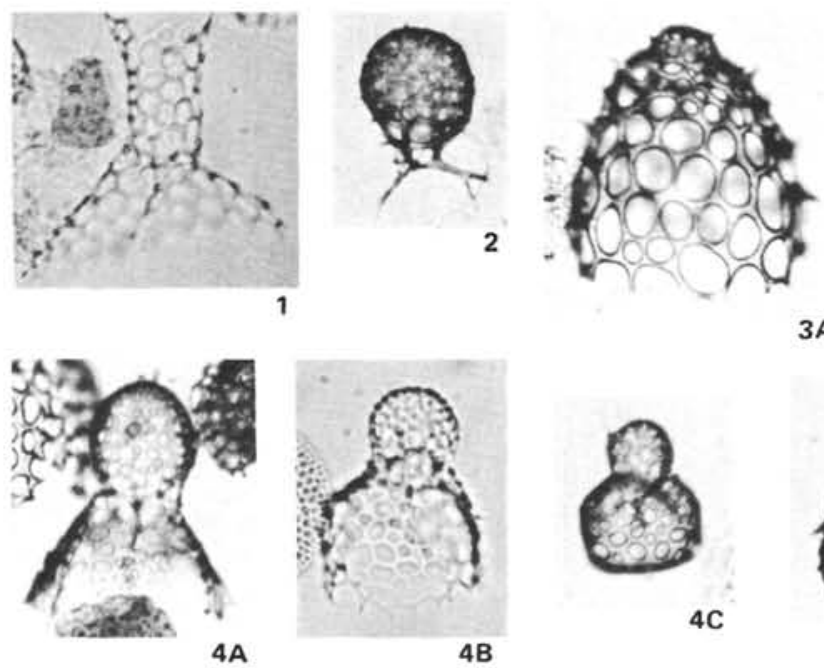

$3 A$
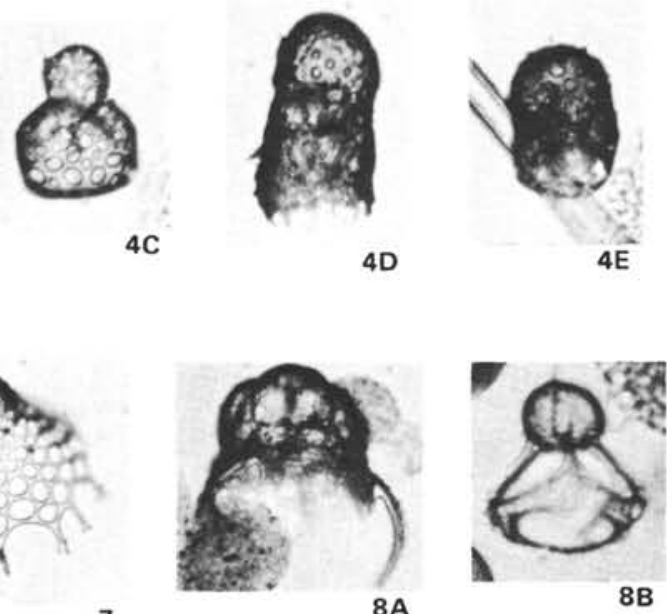

7
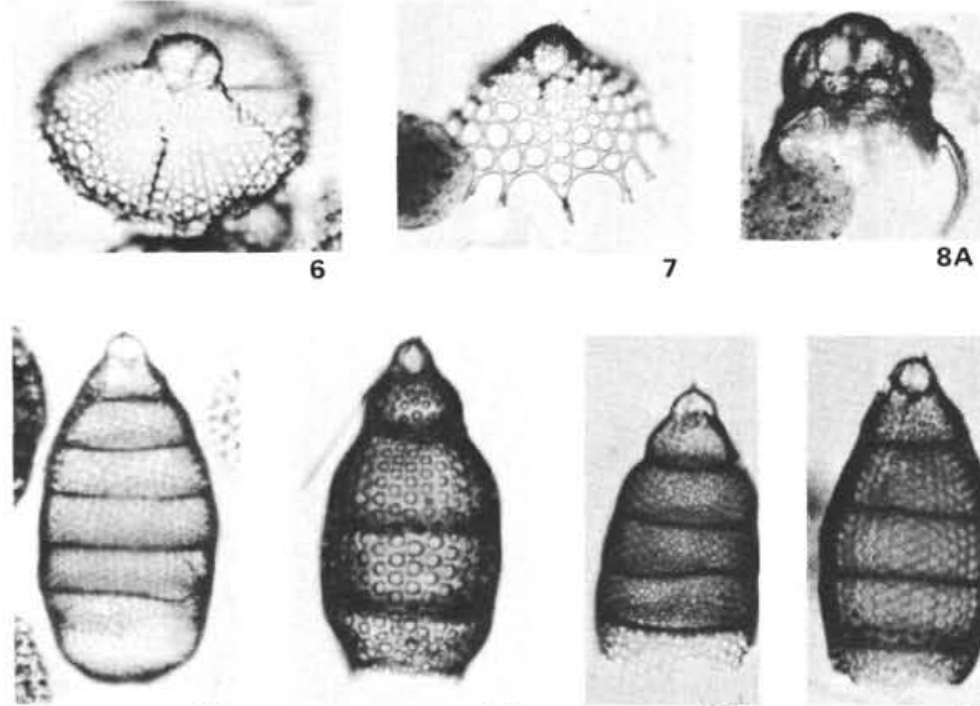

12

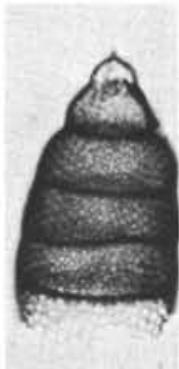

$13 \mathrm{~A}$

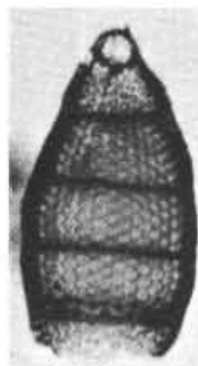

$13 B$

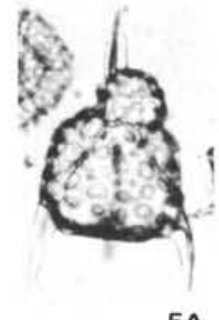

5A
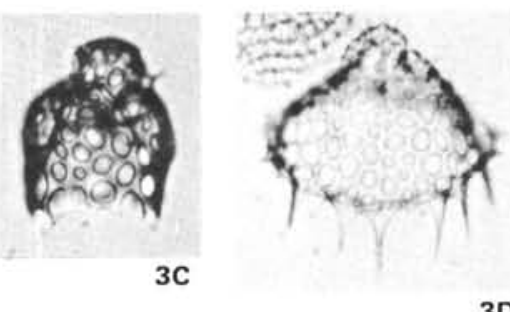

3D

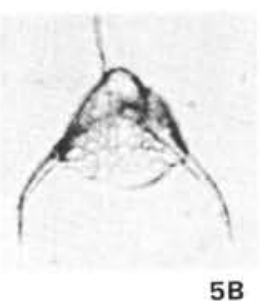

5B
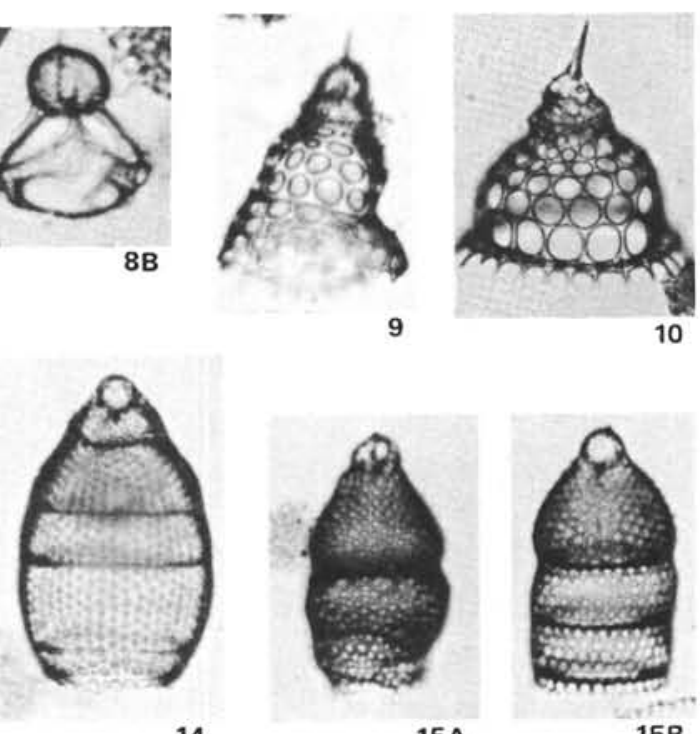

14
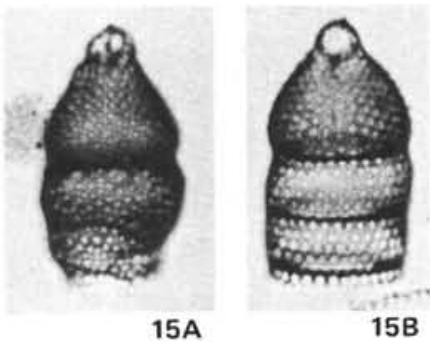

Plate 4. Radiolarians, $230 \times$. 1. Amphiplecta group: Sample 552A-28,CC, Sl.2, U8/3. 2. Arachnocorallium group: Sample 552A-12-1, 95-97 cm, Sl.2, Q21/0. 3. Ceratocyrtis group, (A) Sample 552-5,CC, Sl.2, V12/4; (B) Sample 552A-27,CC, Sl.1, W12/1; (C) Sample 552-4-2, 91-93 cm, Sl.1, K43/4. (D) Sample 552A-26-1, 65-66 cm, Ph. 1, W44/3. 4. Lophophaena group, (A) Sample 552-5,CC, Sl.2, S14/4; (B) Sample 552-4-2, 91-93 cm, Sl.1, F11/4; (C) Sample 552A-14-1, 30-31 cm, Sl.1, G40/1; (D) Sample 552A-14-3, 11-12 cm, Sl.1, V14/0; (E) Sample 552A-19,CC, Sl.2, W31/0. 5. Pseudodictyophimus group, (A) Sample 555-15-1, 40-42 cm, Sl.1, Q10/4; (B) Sample 552A-15-3, 11-12 cm, Sl.1, K20/4. 6. Sethophormin group A: Sample 552A-19,CC, Sl.2, T33/3. 7. Sethophormin group B: Sample 552A-1,CC, Sl.2, C34/0. 8. Other Plagoniids, (A) Sample 552A-28,CC, Sl.1, E29/0; (B) Sample 552A-28,CC, Sl.1, K29/4. 9. Cycladophora davisiana: Sample 552A-1,CC, Sl. 2, H9/2. 10. Eucecryphalus group: Sample 552A-12-1, 95-97 cm, Sl.2, U9/0. 11. Eucyrtidium acuminatum Sample 552A-19,CC, Sl.2, M36/3. 12. Eucyrtidium calvertense: Sample 552A-19,CC, Sl.2, T15/3. 13. Eucyrtidium cienkowskii group, (A) Sample 552-4-2, 91-93 cm, Sl.1, B34/3; (B) Sample 555-17-1, 44-46 cm, Sl.2, Q15/0. 14. Eucyrtidium hexagonatum: Sample 552A-27,CC, SI.1, B10/0. 15. Eucyrtidium punctatum, (A) Sample 552A-14-1, 30-31 cm, Sl.1, S26/4; (B) Sample 552A-14-1, 30-31 cm, Sl.1, H40/4. 


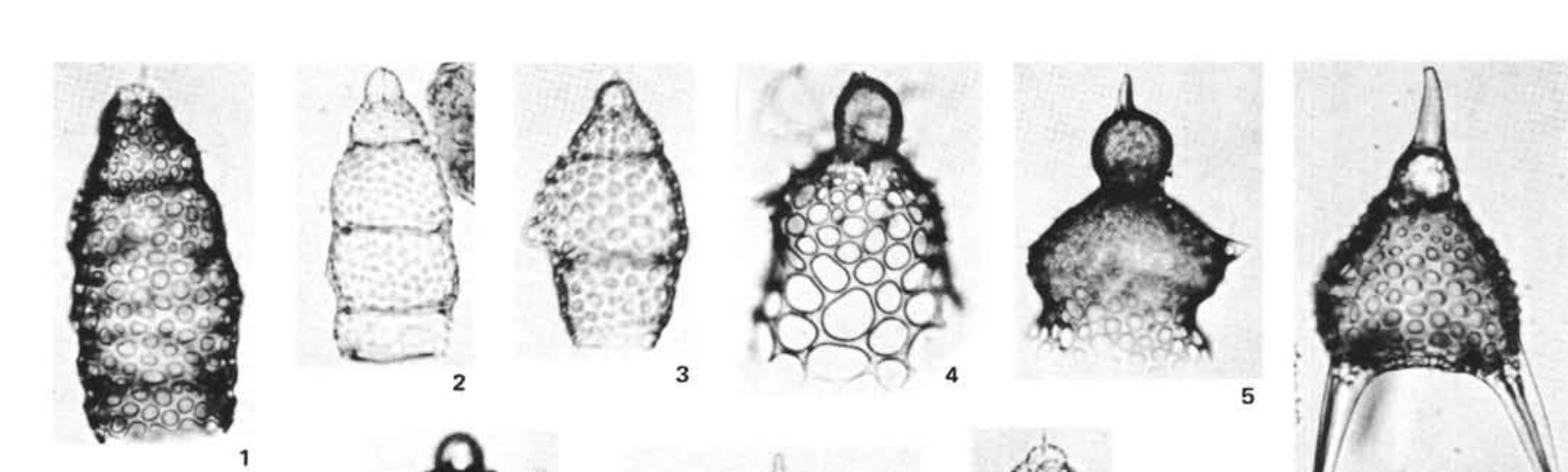

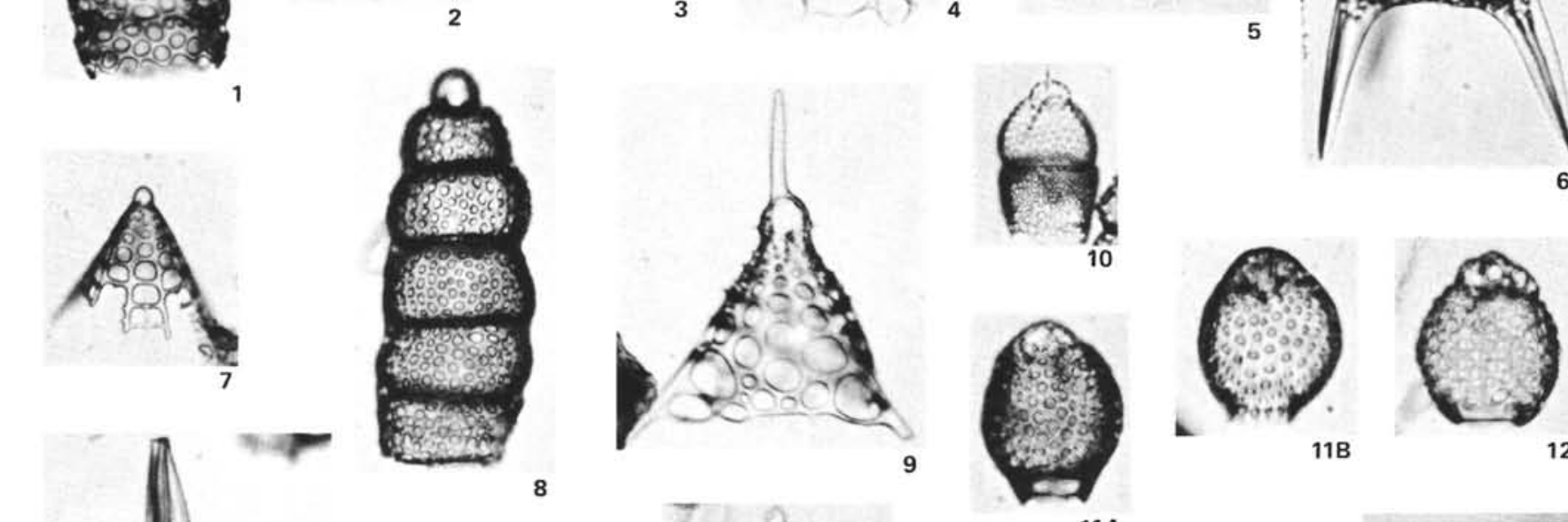

as 0 á 


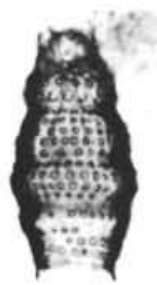

$1 \mathrm{~A}$
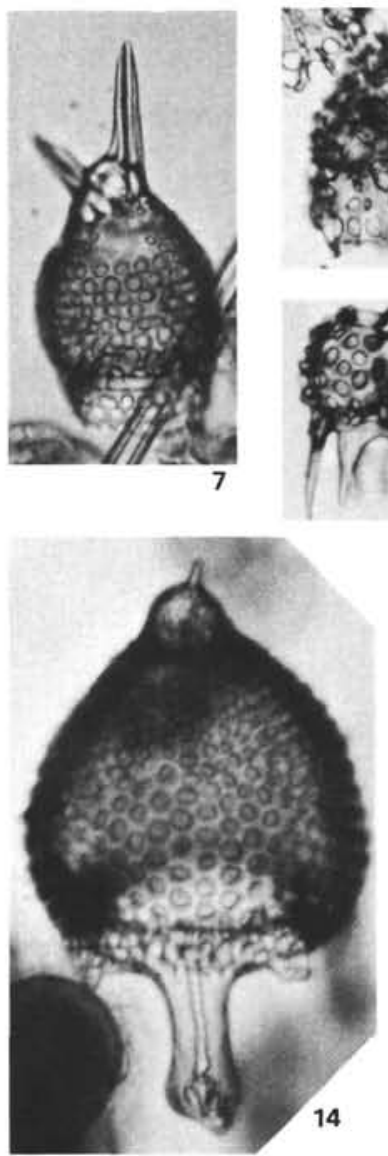

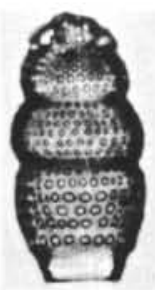

2A

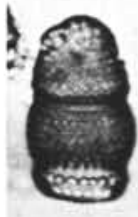

2B

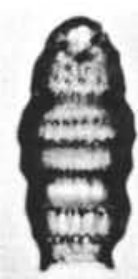

3

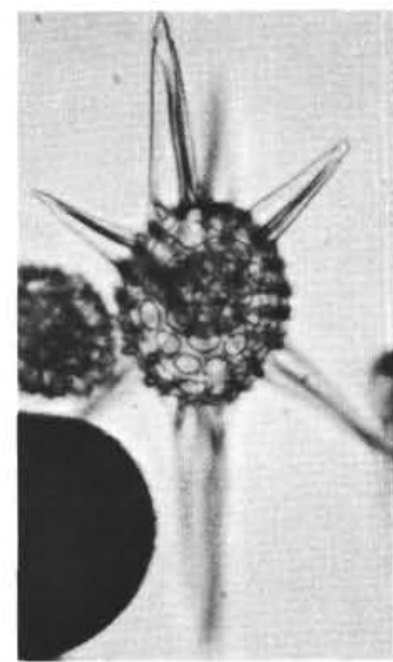

11

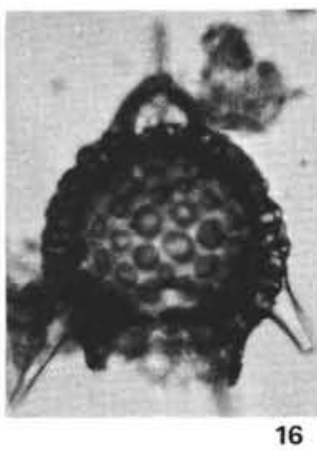

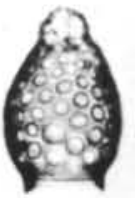

5
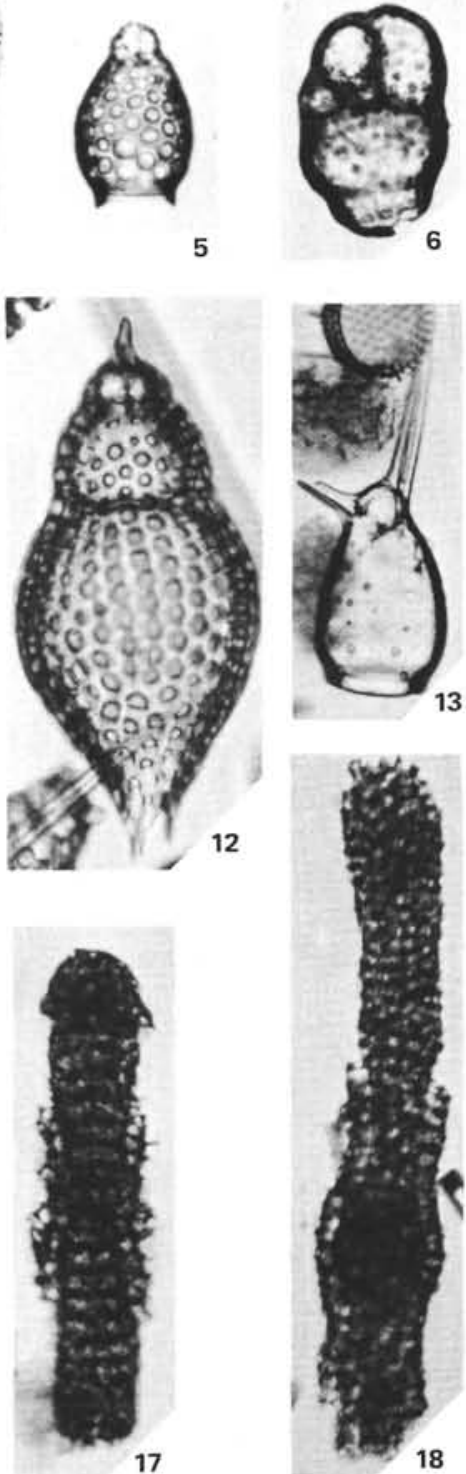

Plate 6. Radiolarians, $230 \times$. 1. Botryostrobus group, (A) Sample 552-3,CC, Sl.1, R9/3; (B) Sample 552-3,CC, Sl.1, Q19/0. 2. Phormostichoartus group, (A) Sample 552-4-2, 91-93 cm, Sl.1, K15/0; (B) Sample 552A-14-1, 30-31 cm, Sl.1, C14/0. 3. Siphocampe group: Sample 5524-2, 91-93 cm, Sl.1, J19/0. 4. Spirocyrtis group: Sample 552A-12-1, 95-97 cm, S1.2, X36/2. 5. Carpocanarium group: Sample 552-5,CC, Sl.2, N17/1. 6. Cannobotryid group: Sample 552-4-2, 91-93 cm, S1.1, H10/4. 7-18 Eocene radiolaria. 7. Lophocyrtis norvegiensis: Sample 552-10,CC, Ph.1, L19/3. 8. Ceratocyrtis sp.: Sample 552A-37-3, 62-63 cm, Sl. 2, C9/4. 9. Ceratospyris sp.: Sample 552A-37-3, 62-63 cm, Sl. 2, T17/0. 10. Pterocodon ampla: Sample 552-10,CC, SI.2, H24/4. 11. Stylosphaera goruna: Sample 552-10,CC, Sl.2, R47/1. 12. Phormocyrtis striata striata: Sample 552-10,CC, Ph. 1, F39/3. 13. Lophocyrtis biaurita: Sample 553A-10-1, 122-124 cm, Sl.2, C39/4. 14. Lychnocanoma amphitrite: Sample 553A-10-1, 122-124 cm, Sl.2, F10/3. 15. Lamptonium obelix: Sample 553A-10-2, $122-124 \mathrm{~cm}, \mathrm{Sl} .2, \mathrm{U} 22 / 1$. 16. Lamptonium pennatum: Sample $553 \mathrm{~A}-10-5,98-100 \mathrm{~cm}, \mathrm{Sl} .2, \mathrm{D} 15 / 1$. 17. Amphymenium splendiarmatum: Sample $553 \mathrm{~A}-10-1,122-124 \mathrm{~cm}$, S1.2, B7/0. 18. Amphicraspedum prolixum: Sample 553A-11-4, 129-130 cm, Sl.1, T25/3. 